\title{
Article \\ Nutritional Composition, Bioactive Compounds, and Volatiles Profile Characterization of Two Edible Undervalued Plants: Portulaca oleracea L. and Porophyllum ruderale (Jacq.) Cass
}

\author{
Tamara Fukalova Fukalova ${ }^{1}$ (D) María Dolores García-Martínez ${ }^{2}$ id and María Dolores Raigón ${ }^{2, *}$ (D) \\ 1 Laboratorio de Fitoquímica y Productos Biológicos, Facultad de Ciencias Químicas, Universidad Central del \\ Ecuador, Quito 170521, Ecuador; tfukalova@uce.edu.ec \\ 2 Instituto de Conservación y Mejora de la Agrobiodiversidad Valenciana, Universitat Politècnica de València, \\ 46022 Valencia, Spain; magarma8@qim.upv.es \\ * Correspondence: mdraigon@qim.upv.es; Tel.: +34-963-877347
}

Citation: Fukalova Fukalova, T.; García-Martínez, M.D.; Raigón, M.D. Nutritional Composition, Bioactive Compounds, and Volatiles Profile Characterization of Two Edible Undervalued Plants: Portulaca oleracea L. and Porophyllum ruderale (Jacq.) Cass. Plants 2022, 11, 377. https://doi.org/10.3390/

plants11030377

Academic Editors: Vincenzo De Feo and Lucia Caputo

Received: 10 January 2022

Accepted: 26 January 2022

Published: 29 January 2022

Publisher's Note: MDPI stays neutral with regard to jurisdictional claims in published maps and institutional affiliations.

Copyright: (C) 2022 by the authors. Licensee MDPI, Basel, Switzerland. This article is an open access article distributed under the terms and conditions of the Creative Commons Attribution (CC BY) license (https:// creativecommons.org/licenses/by/ $4.0 /)$.

\begin{abstract}
Wild edible plants are an important source of healthy food and have played an important role in traditional Mediterranean diets. In this paper, quality characteristics were typified in Portulaca oleracea L. and Porophyllum ruderale (Jacq.) Cass, undervalued plants inherent to the springsummer season in the Valencian coastal region. Nutritional composition and bioactive compounds were analyzed and compared between plants in wild and organic cultivation conditions. Proximate analysis was carried out according to Association of Official Analytical Chemists methods. Total antioxidants were measured as 2.2-diphenyl-1-picrylhydrazyl hydrate and total polyphenols content via the Folin-Ciocalteu procedure. The HS-SPME technique was used to characterize the volatiles profile, and the polyphenol profile was evaluated by HPLC. The most important microelement was iron. Total antioxidants ranged from 4392.16 to $7315.00 \mu \mathrm{mol}$ Trolox equivalents $100 \mathrm{~g}^{-1} \mathrm{fw}$, and total phenolic content ranged from 99.09 to $391.18 \mathrm{mg}$ gallic acid equivalents $100 \mathrm{~g}^{-1} \mathrm{fw}$. Results show that the content of antioxidants and phenols was higher in wild species than in cultivated ones. The volatiles profile revealed that $P$. ruderale was rich in monoterpenoids (48.65-55.82\%), and fatty alcohols were characteristic in P. oleracea species (16.21-54.18\%). The results suggest that both plants could be healthy foods and could have new sustainable agro-ecological potential for the local commercial sector.
\end{abstract}

Keywords: healthy food; quality characteristics; nutritional composition; bioactive compounds; volatiles profile; undervalued plants

\section{Introduction}

The Food and Agriculture Organization of the United Nations estimates that 75\% of the genetic diversity of the world's crops has been lost. Of the 7000 species that have been used as food, fiber, textile, medicine throughout history, only about 150 are cultivated for human and animal consumption [1]. The rest of plant species are underused and undervalued, causing loss of agrobiodiversity in territories [2,3], even though many of these plants have high economic, ecological, and food potential. Factors such as climate change, deforestation, and cultural erosion influence the disappearance of many plant species that at times were very important in human intake as healthy food, giving them the status of undervalued, with serious consequences for agriculture, nutrition, and food security [4]. In a context of climate, environmental, and social crisis, undervalued plant species are considered important to farms and farmers [5].

Providing the growing world population with healthy food based on sustainable and alternative food systems is a pressing social challenge of the 21st century [6], even more so considering the situation generated by the COVID pandemic, which essentially 
highlighted the need for change in many aspects of modern life, among which include food sustainability and the conservation of undervalued plants as future resources $[7,8]$.

Today, part of this ethnobotanical heritage is being recovered, providing technical scientific information on the species composition, botanical value, and potential for current and future uses $[9,10]$. Originally, one of the identifying characteristics of the traditional Mediterranean diet was the introduction of the closest edible resources, which allowed for the incorporation of wild plants for consumption, some of which are still valid in current elaborations, forming part of the local dishes and enriching them with flavor and nutritional value. The gathering of wild edible plants is linked to their seasonality and is part of the traditional regional knowledge. Being seasonal plants, they play a fundamental role in response to climate changes due to their long process of natural selection [11,12].

Many plants have been revaluated and have received considerable attention, mainly focusing on ethnobotanical and pharmacological aspects. The potential of edible plants in terms of their nutritional and bioactive benefits have been investigated only in a few cases, despite representing a particular aspect of local biodiversity and being an important food source, especially in the Mediterranean Basin [13-15]. In this region, the environment is characterized by a greater abundance of endemic flora. The richness and diversity of wild species, their collection times, and edaphoclimatic and growing environments make it difficult to standardize their nutritional composition, causing heterogeneity of their components [16-19]. Consequently, the highest contents of bioactive components are obtained by respecting their temporality and optimal vegetative development [10].

Mediterranean traditions have made it possible for a considerable number of wild plants to remain present in the human diet [20]. These plants are still consumed locally, alone or in combination with cultivated species, in various ways, such as fresh (salad), cooked (soup and boiled), and as condiments for their organoleptic properties. The seasonal consumption of undervalued species allows, on the one hand, to minimize the resources used for their growth, since they easily adapt to environmental conditions, and on the other hand, offers a range of foods with seasonal alternatives throughout the year, providing a variety of meals and the development of a sustainable cuisine [21,22]. Consuming these plants prevents chronic degenerative diseases, cardiovascular diseases, and obesity, among others [23,24]. For this reason, traditional food items resort to the use of edible plants that are indistinguishable from medicinal plants, both of which form part of the biocultural diversity and regional culinary traditions [25]. The increasing demand for healthy foods is renewing interest in the use and research of undervalued wild edible plants.

Currently, conventional crops have displaced many of the once known and appreciated wild species, making them undervalued. Among these undervalued species are Portulaca oleracea and Porophyllum ruderale, both inherent to the spring-summer season in Mediterranean conditions. According to a previous ethnobotanical review, these selected plants have cultural relevance and are deeply rooted in the traditional cuisine of the Valencian coast [26-31].

Although they are edible wild species and are accessible owing to their abundance during their season, their nutritional and bioactive composition, as well as their phenolic and volatile profiles, have not been scientifically reinforced. Given this situation, we have proposed the following hypothesis: the undervalued edible species $P$. ruderale and $P$. oleracea provide variability in their nutritional, aromatic, and bioactive compounds depending on the environment's growing conditions. For this purpose, the proximate analysis and quantification of bioactive components, in addition to other chemical constituents and the organoleptic matrix, were carried out. An analysis of the volatiles profile, which contains high-value functional components, was performed by headspace solid phase microextraction (HS-SPME) and gas chromatography mass spectrometry (GC/MS), and an analysis of the polyphenol profile was performed by HPLC. This work aims to be a reference to promote the inclusion of these plants as a nutritional alternative given the high demand for a balanced and healthy diet, and at the same time, due to their wide presence in the corresponding season, to diversify the intake of food and promote the use of traditional 
gastronomy, thereby establishing a sustainable path for potential new crops. This work also evaluated the differences between the composition of the two species in wild conditions and in organic farming conditions.

\section{Results}

The proximate nutritional compositions of fresh leaves and small tender stems of $P$. ruderale and $P$. oleracea were evaluated; this also included the most representative macrominerals and microminerals. In addition, the bioactive constituents were characterized under wild and organic farming conditions. Each sample consisted of approximately $1.5 \mathrm{~kg}$ of fresh plant with random collection. The data obtained are presented in Table 1. The results are reported as the mean of replicates, alongside the coefficients of variability $(\mathrm{CV})$ of each value and $p$-value, which test the statistical significance of the estimated effect of environment growing conditions.

\subsection{Proximate Composition}

P. oleracea was the species with higher leaf moisture, which oscillated between $83.12 \%$ and $88.39 \%$; in the case of P. ruderale, it ranged between $76.64 \%$ and $84.70 \%$. In both species, the moisture content of the fresh parts increased under the wild growing conditions with significant differences, and variability of this parameter was low in all cases (between $0.03-1.31 \%$ ). The dry matter content in the plants tested ranged from $11.61 \mathrm{~g} \cdot 100 \mathrm{~g}^{-1}$ to $23.36 \mathrm{~g} \cdot 100 \mathrm{~g}^{-1}$; the values of this parameter were significantly different between the cultivated and wild conditions for P. ruderale $(p=0.0000)$ and P. oleracea $(p=0.0140)$. The ash level was lower in species grown in wild conditions compared to their counterparts grown in cultivated conditions, and this difference was accentuated in P. ruderale $(p=0.0020)$. The amount of ash was high in P. oleracea with $2.62 \%$ (wild) and $3.39 \%$ (cultivated). Foliar crude protein concentration was found to be higher in wild growth conditions (1.89\%) in the case of $P$. ruderale, presenting significant differences from its counterpart in organic cultivation conditions $(p=0.0002)$. For P. oleracea, the same patterns were observed without differences between wild and cultivated conditions. Fat accumulation in the leaves of the species studied was very low and its distribution was uneven across growing systems. For $P$. ruderale, the highest concentrations, with significant differences $(p=0.0156)$, were found in wild cultivation conditions $(0.66 \%)$. For P. oleracea, the fat in the plants from the cultivated environment $(0.99 \%)$ was three times higher than that of its counterpart in wild conditions. No difference in fiber levels were observed between the species studied in the two conditions, and they ranged from 2.39 to $5.50 \%$. Carbohydrate levels were higher in P. ruderale, with a maximum in the cultivated species $(17.50 \%)$. The same trends occurred in $P$. oleracea, with a higher level of this parameter reached in the cultivated species $(8.41 \%)$. The significant differences were more pronounced in $P$ ruderale $(p=0.0008)$. Energy values ranged from 28.0 to $78.75 \mathrm{kcal} \cdot 100 \mathrm{~g}^{-1}$ fresh weight, with higher levels in cultivated plants compared to wild plants.

The coefficient of variety $(\mathrm{CV})$ showed a wide discrepancy in the nutritional parameters such as crude fiber and carbohydrates, with $34.18 \%$ and $51.32 \%$, respectively, in wild $P$. ruderale, demonstrating the excessive dispersion. In contrast, $P$. oleracea had the highest variability for nutritional parameters such as crude fiber (34.23\%) and carbohydrates $(10.22 \%)$ in cultivated species. The remaining parameters were less variable, with coefficients of variability oscillating between $0.03 \%$ and $5 \%$. The nutritional parameters that showed the least variability value were protein $(0.05 \%)$ and fat $(0.10 \%)$. 
Table 1. Nutritional and bioactive compounds: mean value \pm standard error for each parameter analyzed; coefficient of variability (CV) and probability ( $p$-value) for the significance of differences between the environmental growing conditions of $P$. ruderale and $P$. oleracea.

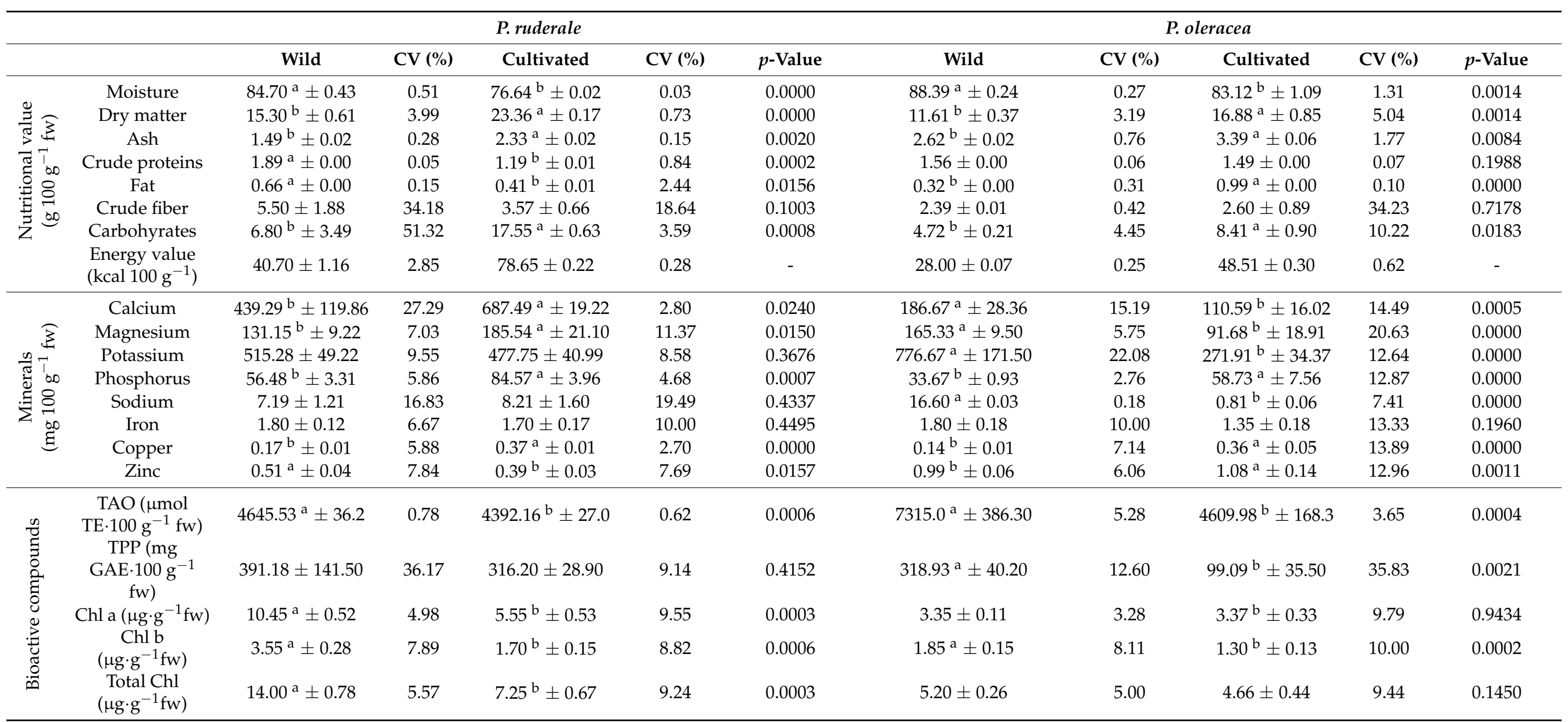

Note: TAO: total antiox 


\subsection{Mineral Composition}

The mineral composition of studied plants was measured and is recorded in Table 1. The most abundant macromineral in the edible parts was potassium in wild conditions for P. ruderale (515.28 mg.100 $\mathrm{g}^{-1} \mathrm{fw}$ ) and for P. oleracea $\left(776.67 \mathrm{mg} \cdot 100 \mathrm{~g}^{-1} \mathrm{fw}\right)$, with no significant difference between growing conditions $(p>0.05)$ for P. ruderale and a significant difference for P. oleracea $(p=0.0000)$. Other abundant macrominerals were calcium and magnesium, which showed significant differences between growth environments, especially in P. oleracea ( $p=0.0005$ and $p=0.0000$, respectively). The most prominent micromineral was Fe, with the highest content $\left(1.80 \mathrm{mg} \cdot 100 \mathrm{~g}^{-1} \mathrm{fw}\right)$ in species from wild conditions for both plants, although there were no significant differences between growth conditions. The greatest mineral variability occurred for $P$. ruderale in calcium $(27.29 \%)$ and potassium $(9.55 \%)$ content when in wild conditions and sodium $(19.49 \%)$ in cultivated conditions. In P. oleracea, calcium (15.19\%) and potassium (22.08\%) contents were the least stable for wild species, together with copper $(7.14 \%)$.

The comparison of the nutritional composition as a function of the growth environment of each species was carried out considering statistically significant effects ( $p$-value), which are indicated in Table 1 with the letters as a super index for each parameter analyzed, except for the caloric value obtained by calculation. The nutritional parameters with $p=0.0000$ are the ones that differ the most depending on the growing environment.

\subsection{Non-Nutritional Compounds}

The non-nutritional compounds (considered by some authors as bioactive components [32]) were quantified and are presented in Table 1. These were antioxidants, total phenolic content, and chlorophylls ( $a, b$, and total). The amount of total antioxidants in the fresh wild samples of both plants stood out, ranging from 4645.53 to 7315.0 ( $\mu$ mol $\mathrm{TE} \cdot 100 \mathrm{~g}^{-1} \mathrm{fw}$ ), with significant differences from the cultivated species. On the contrary, the total polyphenol content in P. ruderale was higher, although there was no significant difference between wild and cultivated species; the difference was significant in P. oleracea $(p=0.0021)$. However, the total phenols values presented the greatest variability among all the parameters studied, especially in wild P. ruderale $(36.17 \%)$, followed by cultivated P. oleracea $(35.83 \%)$. Chlorophyll content $(a, b$, and total) in fresh plant samples were higher in wild plants for both species, although significant differences between growing conditions were only present in $P$. ruderale, where the wild species was double the cultivated species for these parameters.

Similarly, Table 1 shows the significance value ( $p$-value) for each of the bioactive compounds analyzed in the edible parts of the studied species, indicating the difference in their levels between wild and cultivated species, with the letters as a super index.

\subsection{Polyphenols Profilere}

In total, ten polyphenolic compounds from two categories-hydroxycinnamic acids and flavonoids-were identified and are listed in Table 2. Five phenolic compounds were detected in both species under the two growing conditions. They were hydroxycinnamic acids: chlorogenic, caffeic and p-coumaric acids; and flavonoids: quercetin and kaempferol. Three components were detected in $P$. ruderale and corresponded to gallic acid, rutin, and luteolin. The most abundant phenolic compound was chlorogenic acid in $P$. ruderale for both growing conditions without a significant difference between them, followed by $p$-coumaric acid with a higher concentration in cultivated organic conditions. 
Table 2. Individual hydroxycinnamic acid and flavonoid content of P. ruderale and P. oleracea species.

\begin{tabular}{|c|c|c|c|c|c|c|c|c|c|}
\hline & & \multicolumn{3}{|c|}{ P. ruderale } & \multicolumn{5}{|c|}{ P. oleracea } \\
\hline & & Wild & Cultivated & $p$-Value & $S$ & Wild & Cultivated & $p$-Value & $S$ \\
\hline \multirow{4}{*}{ 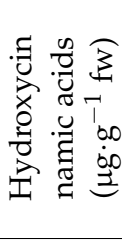 } & Gallic acid & $1.13 \pm 0.07$ & $0.41 \pm 0.07$ & 0.0002 & $* *$ & nd & nd & - & - \\
\hline & $\begin{array}{l}\text { Chlorogenic } \\
\text { acid }\end{array}$ & $798.45 \pm 36.52$ & $780.08 \pm 0.85$ & 0.4329 & ns & $6.75 \pm 1.09$ & $11.38 \pm 2.64$ & 0.0399 & $*$ \\
\hline & Caffeic acid & $3.93 \pm 0.16$ & $1.67 \pm 0.03$ & 0.0000 & $* *$ & $5.72 \pm 0.29$ & $16.25 \pm 0.82$ & 0.0000 & $* *$ \\
\hline & $\begin{array}{l}p \text {-Coumaric } \\
\text { acid }\end{array}$ & $54.8 \pm 2.26$ & $175.21 \pm 1.28$ & 0.0000 & $* *$ & $4.21 \pm 0.17$ & $17.99 \pm 1.19$ & 0.0000 & $* *$ \\
\hline \multirow{6}{*}{ 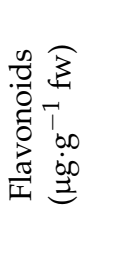 } & Myricetin & nd & $1.54 \pm 0.10$ & - & - & $0.95 \pm 0.04$ & $10.26 \pm 0.62$ & 0.0000 & $* *$ \\
\hline & Rutin & $14.73 \pm 0.70$ & $15.43 \pm 0.46$ & 0.2242 & ns & nd & nd & - & - \\
\hline & Quercetin & $40.42 \pm 2.44$ & $49.95 \pm 0.86$ & 0.0031 & $*$ & $0.21 \pm 0.03$ & $0.47 \pm 0.01$ & 0.0002 & $* *$ \\
\hline & Luteolin & $3.98 \pm 0.22$ & $7.3 \pm 0.13$ & 0.0000 & $* *$ & nd & nd & - & - \\
\hline & Kaempferol & $5.84 \pm 0.36$ & $13.76 \pm 0.61$ & 0.0000 & $* *$ & $0.09 \pm 0.01$ & $0.30 \pm 0.04$ & 0.0006 & $* *$ \\
\hline & Apigenin & $2.48 \pm 0.36$ & $3.59 \pm 0.09$ & 0.0068 & * & nd & $0.96 \pm 0.06$ & - & - \\
\hline
\end{tabular}

Note: All data are expressed as means \pm standard error, $n=3 ; \mathrm{ns},{ }^{*}$ and, ${ }^{* *}$ indicate that the $\mathrm{F}$ test is not significant or significant at $p<0.05$ and $p<0.01$, respectively. Wild and organic cultivated growth conditions were compared by $t$-test; nd: not detected; S: significance.

Gallic acid was not detected in P. oleracea and other phenolic compounds were higher in cultivated than in wild conditions with significant differences. For flavonoids, six different compounds were identified in P. ruderale and four in P. oleracea, without rutin or luteolin. Quercetin and myricetin as major compounds as a major compounds P. ruderale were only detected in its cultivated species. Myricetin in P. oleracea was higher, being significantly increased in organic cultivation conditions, and apigenin was detected only in the cultivated species.

Organic production systems were favorable for the synthesis of flavonoids in the two undervalued species. They also favored the synthesis of polyphenolic compounds in $P$. oleracea, but only $p$-coumaric acid synthesis in $P$. ruderale.

\subsection{Other Chemicals}

Other chemical components determined were nitrates and parameters related to the acidification of edible leaves ( $\mathrm{pH}$ and total acidity); the are results presented in Figure 1. In both species, the nitrate concentration in fresh plant samples was higher in wild species than in cultivated species, with statistically significant differences $(p<0.05)$, showing a higher level in P. ruderale (777.3 $\mathrm{mg} \mathrm{NO}_{3}{ }^{-} \mathrm{kg}^{-1} \mathrm{fw}$ ) compared to P. oleracea (471.0 $\mathrm{mg} \mathrm{NO}_{3}{ }^{-}$ $\left.\mathrm{kg}^{-1} \mathrm{fw}\right)$. Similarly, the $\mathrm{pH}$ value was significantly higher in wild plants compared to cultivated plants, and its highest value was recorded in P. olerace (6.6). Being inversely proportional, the titratable acidity showed opposite behavior in terms of $\mathrm{pH}$, in which the cultivated samples presented higher values than the wild ones in terms of acidity. Total acidity did not show a significant difference between growing conditions in the case of P. oleracea (range $0.14-0.19 \%$ ), while there was a significant difference in the case of $P$. ruderale (range $0.10-0.20 \%$ ). 

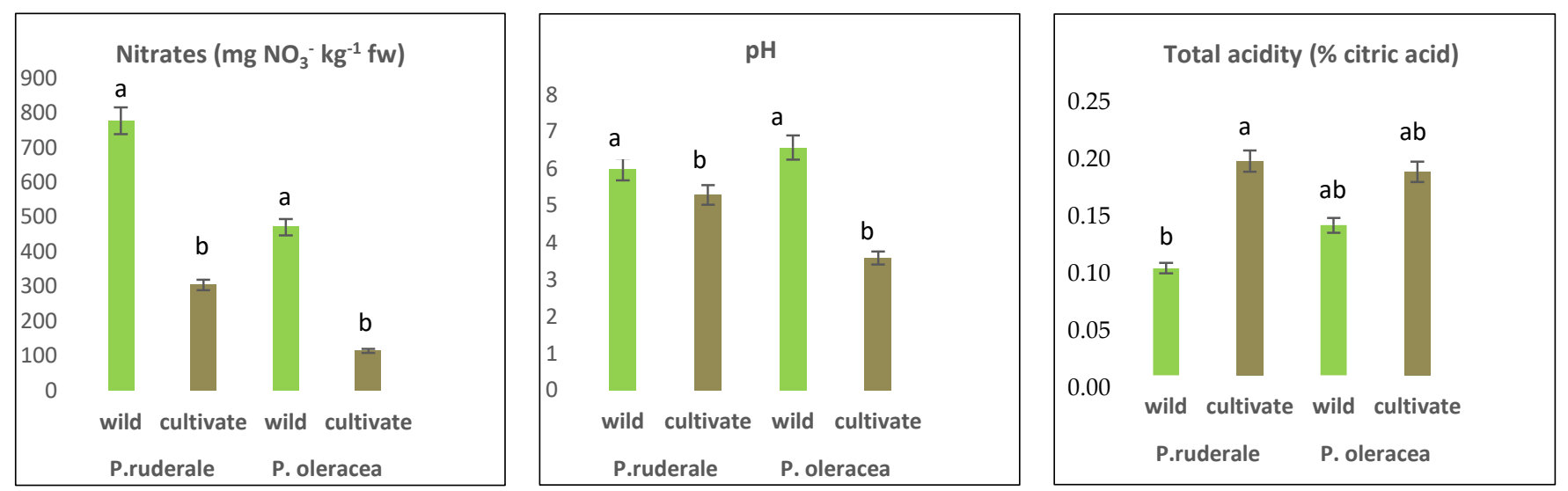

Figure 1. Nitrate concentrations, $\mathrm{pH}$, and total acidity in fresh edible parts of $P$. ruderale and P. oleracea. The significant differences are visualized in letters. The letters $a, b$ showed that difference exist and ab showed that difference not exist.

\subsection{Correlations between Quality Parameters}

The study of the correlations between nutritional, mineral, and bioactive compounds in the two plants studied showed different degrees of correlation between them. These correlations are presented for P. ruderale in Table 3 and for P. oleracea in Table 4. Since total chlorophyll is the sum of chlorophylls a and $\mathrm{b}$, only its correlation is presented.

Table 3. Pearson's correlation coefficient among the nutritional, mineral, and bioactive compounds of edible parts of $P$. ruderale.

\begin{tabular}{|c|c|c|c|c|c|c|c|c|c|c|c|c|c|c|c|}
\hline & $\mathrm{CP}$ & FT & $\mathrm{CF}$ & $\mathrm{CH}$ & $\mathrm{Ca}$ & $\mathrm{Mg}$ & K & $\mathbf{P}$ & $\mathrm{Na}$ & $\mathrm{Fe}$ & $\mathrm{Cu}$ & $\mathrm{Zn}$ & TAO & TPP & TCh \\
\hline FT & $\underset{*}{0.879}$ & 1 & & & & & & & & & & & & & \\
\hline $\mathrm{CF}$ & 0.685 & 0.798 & 1 & & & & & & & & & & & & \\
\hline $\mathrm{CH}$ & -0.956 & $\begin{array}{c}-0.908 \\
*\end{array}$ & $-\underset{*}{-0.856}$ & 1 & & & & & & & & & & & \\
\hline $\mathrm{Ca}$ & $\underset{*}{-0.854}$ & -0.740 & -0.792 & $\underset{*}{0.914}$ & 1 & & & & & & & & & & \\
\hline $\mathrm{Mg}$ & $\begin{array}{c}-0.949 \\
*\end{array}$ & $\begin{array}{c}-0.836 \\
*\end{array}$ & -0.634 & $\underset{*}{0.871}$ & 0.771 & 1 & & & & & & & & & \\
\hline K & 0.465 & 0.298 & 0.625 & -0.541 & -0.439 & -0.481 & 1 & & & & & & & & \\
\hline $\mathrm{P}$ & $\underset{*}{-0.947}$ & $\begin{array}{c}-0.938 \\
*\end{array}$ & -0.832 & $\begin{array}{c}0.989 \\
*\end{array}$ & $\begin{array}{c}0.868 \\
*\end{array}$ & $\begin{array}{c}0.840 \\
*\end{array}$ & -0.461 & 1 & & & & & & & \\
\hline $\mathrm{Na}$ & -0.410 & -0.054 & -0.036 & 0.317 & 0.17 & 0.313 & -0.615 & 0.298 & 1 & & & & & & \\
\hline $\mathrm{Fe}$ & 0.463 & 0.209 & 0.139 & -0.335 & -0.109 & -0.540 & 0.721 & -0.296 & -0.814 & 1 & & & & & \\
\hline $\mathrm{Cu}$ & $\underset{*}{-0.983}$ & $\underset{*}{-0.917}$ & -0.715 & $\underset{*}{0.967}$ & $\underset{*}{0.834}$ & $\underset{*}{0.888}$ & -0.415 & $\underset{*}{0.980}$ & 0.385 & -0.386 & 1 & & & & \\
\hline $\mathrm{Zn}$ & $\begin{array}{c}0.902 \\
*\end{array}$ & 0.656 & 0.599 & $\underset{*}{-0.870}$ & $\underset{*}{-0.940}$ & $\underset{*}{-0.837}$ & 0.446 & $\underset{*}{-0.817}$ & -0.395 & 0.321 & $\underset{*}{-0.848}$ & 1 & & & \\
\hline TAO & $\underset{*}{0.950}$ & $\underset{*}{0.928}$ & $\begin{array}{c}0.812 \\
*\end{array}$ & $\underset{*}{-0.983}$ & $\begin{array}{c}-0.835 \\
*\end{array}$ & $-\underset{*}{-0.842}$ & 0.499 & $\underset{*}{-0.996}$ & -0.368 & 0.368 & $\underset{*}{-0.983}$ & 0.802 & 1 & & \\
\hline TPP & 0.430 & 0.438 & -0.137 & -0.244 & 0.045 & -0.391 & -0.210 & -0.342 & -0.326 & 0.373 & -0.475 & 0.124 & 0.386 & 1 & \\
\hline TCh & $\begin{array}{c}0.990 \\
*\end{array}$ & $\underset{*}{0.836}$ & 0.606 & $\underset{*}{-0.929}$ & $\underset{*}{-0.834}$ & $\underset{*}{-0.908}$ & 0.402 & $\underset{*}{-0.928}$ & -0.464 & 0.446 & $\underset{*}{-0.980}$ & 0.908 & $\underset{*}{0.934}$ & 0.484 & 1 \\
\hline
\end{tabular}

${ }^{*}$ indicates significant difference at $p<0.05 . \mathrm{CP}=$ crude protein; $\mathrm{CF}=$ crude fiber; $\mathrm{CH}=$ carbohydrates; $\mathrm{TAO}=$ total antioxidants; TPP = total polyphenols; $\mathrm{TCh}=$ total chlorophyll. 
Table 4. Pearson's correlation coefficient among the nutritional, mineral, and bioactive compounds of edible parts of $P$. oleracea.

\begin{tabular}{|c|c|c|c|c|c|c|c|c|c|c|c|c|c|c|c|}
\hline & $\mathrm{CP}$ & FT & CF & $\mathrm{CH}$ & $\mathrm{Ca}$ & $\mathrm{Mg}$ & K & $\mathbf{P}$ & $\mathrm{Na}$ & $\mathrm{Fe}$ & $\mathrm{Cu}$ & $\mathrm{Zn}$ & TAO & TPP & TCh \\
\hline FT & -0.597 & 1 & & & & & & & & & & & & & \\
\hline $\mathrm{CF}$ & -0.739 & 0.174 & 1 & & & & & & & & & & & & \\
\hline $\mathrm{CH}$ & -0.517 & $\begin{array}{c}0.880 \\
*\end{array}$ & -0.048 & 1 & & & & & & & & & & & \\
\hline $\mathrm{Ca}$ & 0.403 & -0.884 & -0.034 & -0.808 & 1 & & & & & & & & & & \\
\hline $\mathrm{Mg}$ & 0.438 & $\begin{array}{c}-0.942 \\
*\end{array}$ & 0.001 & $\begin{array}{c}-0.930 \\
*\end{array}$ & $\underset{*}{0.956}$ & 1 & & & & & & & & & \\
\hline K & 0.419 & $\underset{*}{-0.918}$ & -0.166 & -0.787 & $\underset{*}{0.954}$ & $\underset{*}{0.951}$ & 1 & & & & & & & & \\
\hline $\mathrm{P}$ & -0.704 & $\underset{*}{0.947}$ & 0.430 & 0.713 & -0.764 & -0.804 & $-0.852^{*}$ & 1 & & & & & & & \\
\hline $\mathrm{Na}$ & 0.611 & $\underset{*}{-0.999}$ & -0.185 & $\underset{*}{-0.889}$ & $\begin{array}{c}0.895 \\
*\end{array}$ & $\begin{array}{c}0.949 \\
*\end{array}$ & $\begin{array}{c}0.924 \\
*\end{array}$ & $\underset{*}{-0.943}$ & 1 & & & & & & \\
\hline $\mathrm{Fe}$ & 0.359 & -0.809 & -0.100 & $\underset{*}{-0.841}$ & $\begin{array}{c}0.879 \\
*\end{array}$ & $0.929^{*}$ & $0.927^{*}$ & -0.684 & $0.823^{*}$ & 1 & & & & & \\
\hline $\mathrm{Cu}$ & -0.663 & $\begin{array}{c}0.970 \\
*\end{array}$ & 0.343 & 0.760 & -0.793 & $\underset{*}{-0.842}$ & $\underset{*}{-0.870}$ & $\begin{array}{c}0.995 \\
*\end{array}$ & $\underset{*}{-0.965}$ & -0.709 & 1 & & & & \\
\hline $\mathrm{Zn}$ & -0.803 & 0.467 & 0.739 & 0.143 & -0.208 & -0.178 & -0.267 & 0.690 & -0.460 & -0.014 & 0.635 & 1 & & & \\
\hline TAO & 0.634 & $\underset{*}{-0.979}$ & -0.262 & $\underset{*}{-0.831}$ & $\begin{array}{c}0.933 \\
*\end{array}$ & $\begin{array}{c}0.937 \\
*\end{array}$ & $\underset{*}{0.946}$ & $\underset{*}{-0.941}$ & $\begin{array}{c}0.983 \\
*\end{array}$ & $\begin{array}{c}0.823 \\
*\end{array}$ & $\underset{*}{-0.953}$ & -0.500 & 1 & & \\
\hline TPP & 0.774 & $\underset{*}{-0.963}$ & -0.338 & $\underset{*}{-0.853}$ & 0.771 & $\begin{array}{c}0.850 \\
*\end{array}$ & 0.810 & $\underset{*}{-0.956}$ & $\begin{array}{c}0.964 \\
*\end{array}$ & 0.705 & $\underset{*}{-0.965}$ & -0.624 & $\begin{array}{c}0.939 \\
*\end{array}$ & 1 & \\
\hline TCh & -0.664 & 0.001 & 0.589 & 0.164 & -0.071 & -0.040 & 0.007 & 0.033 & -0.036 & -0.140 & -0.0133 & 0.253 & -0.106 & -0.167 & 1 \\
\hline
\end{tabular}

Among the nutrients of P. ruderale, crude protein has the highest number of correlations, with nine strong and significant relationships. Five of these relationships corresponded to a negative correlation with carbohydrates and minerals, and four to a positive correlation with fat, other minerals, and bioactive compounds. A strong positive relationship between crude protein and total chlorophyll was established $(r=0.990)$, which shows the strong relationship between the two parameters of absorbed nitrogen for this species. In contrast, crude protein from P. oleracea did not show any significantly strong relationship. Among the nutrients of P. oleracea, fat showed the highest number of correlations, also with nine strong relationships. Six of these relationships corresponded to a negative correlation with mainly minerals and bioactive compounds. The most complete negative relationship was observed between fat and sodium $(\mathrm{r}=-0.999)$.

Among minerals, copper showed the greatest number of strong relationships, while potassium and sodium showed no strong and significant relations in P. ruderale. In the case of $P$. oleracea, all the minerals showed a highly significant relationship except for $\mathrm{Zn}$. Copper was the micromineral that presented the highest number of strong relationships in both species, such as the total antioxidants of the bioactive components. In general, the strongest negative relationships were observed in P. ruderale, while in P. oleracea positive relationships of similar magnitude prevailed.

\subsection{Volatiles Profile Analysis}

The volatile profile analysis revealed the presence of 11 chemical families. Figure 2 presents the relative percentage of each chemical family of volatile components detected in the fresh aerial parts of the plants studied. The majority of volatile families were: benzenoids, monoterpenoids, medium-chain aldehydes, fatty alcohols, sesquiterpenoids, unsaturated hydrocarbons, and ketones (Figure 2A). The minority volatile families were: organoheterocyclic compounds, pyrazines, organooxygen compounds, and alcohols (Figure 2B). The volatiles profile revealed that $P$. ruderale is rich in monoterpenoids $(48.65-55.82 \%)$, and fatty alcohols are characteristic in P. oleracea species (16.21-54.18\%). 


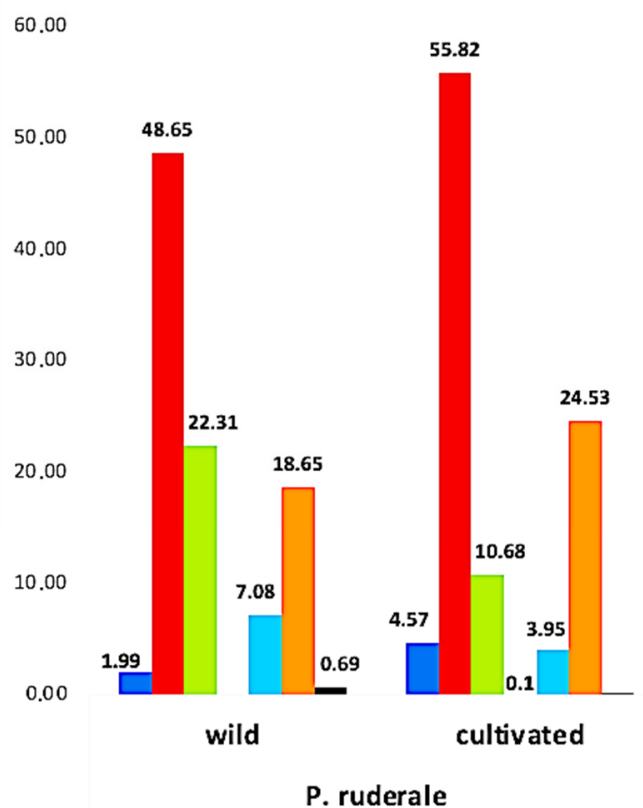

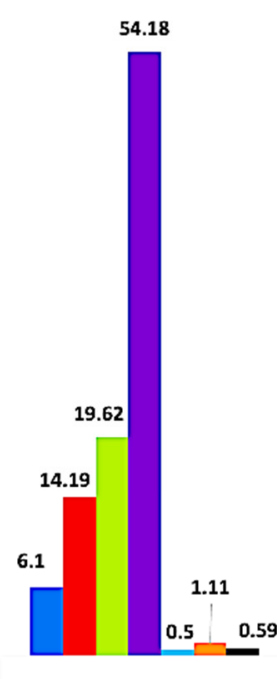

wild

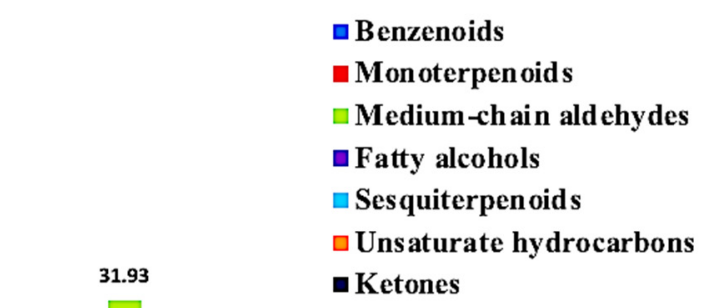

$\square$ Benzenoids

Mon oterpen oid

Sesquiterpen oid

Ketones

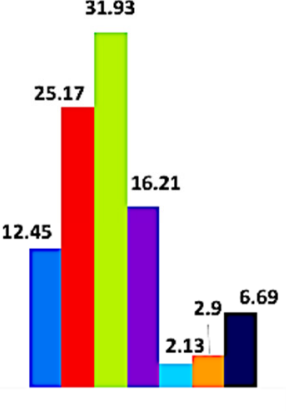

cultivated

P. oleracea

Minority volatile families

B

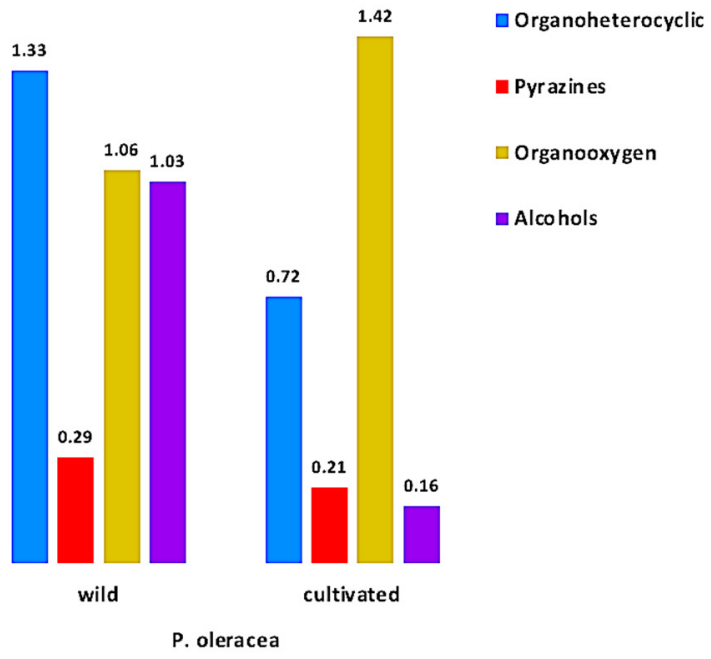

Figure 2. Relative content of the chemical families of volatiles in fresh leaves: (A) majority families of volatiles in wild and cultivated species of P. ruderale and P. oleracea; (B) minority families of volatiles in wild and organic cultivated species of $P$. ruderale and P. oleracea.

Monoterpenoids were present in both species, although they predominated in cultivated P. ruderale $(55.82 \%)$, more than in its wild counterpart $(48.65 \%)$. Unsaturated hydrocarbons were the second family present in both species and stood out in organic cultivated P. ruderale (24.53\%). Another family present in both species and growing environments was medium-chain aldehydes, which was greatest in cultivated P. oleracea (31.93\%). Concerning benzenoid content, P. oleracea stood out in both growing conditions: wild $(6.1 \%)$ and organic farming $(12.45 \%)$. The highest amount of sesquiterpenoids was found in wild P. ruderale $(7.08 \%)$, and cultivated P. oleracea stood out in ketones $(6.69 \%)$. The family of fatty alcohols was characteristics only in P. oleracea, tripling the amount in wild conditions $(54.18 \%)$ compared to cultivated conditions $(12.45 \%)$. The families of smaller quantities are preponderant in P. oleracea, unlike P. ruderale, in both growing conditions. The organoheterocyclic family predominated, especially in the cultivated plants $(1.33 \%)$. 
The next families were organo-oxygens $(1.42 \%)$ and alcohols, which emphasized were most prevalent in wild P. oleracea $(1.03 \%)$. The pyrazine family was more pronounced in P. oleracea, where it reached higher amounts in the wild species $(0.29 \%)$.

\section{Discussion}

As there is little demand for them and a lack of knowledge of their uses, some edible leaf species are undervalued and underused, which contributes to the loss of local agrobiodiversity. The two plants in this study are abundant in the Mediterranean spring-summer season. P. ruderale is an introduced species and P. oleracea an indigenous species. The characterization of nutritional, mineral, and bioactive constituents was carried out with the edible aerial parts of both plants. A bibliographic analysis in reference to these two species showed that their medicinal properties had been studied; on the contrary, there is little information about the nutritional quality and functional properties of these food plants, especially in the case of $P$. ruderale. Characterizing the quantitative properties (amount of nutrients) and qualitative properties (bioactive compounds present) could make an important contribution to the daily requirements of a balanced intake.

The most prominent nutritional parameters characterized were ash (total minerals), protein, fiber, and carbohydrates. Mostly, the nutritional levels of edible plants are related to their lifespan, which in turn depends on the species itself and humidity, temperature, and other environmental factors. The moisture content of the fresh samples of wild species was higher than that of the cultivated species, thus presenting a lower level of dry matter. In the research by Arias-Rico et al. [33], the average values of $85.3 \%$ for moisture in wild Mexican P. ruderale were described. The same species in this study presented similar water content in the same environmental conditions.

On the contrary, the extensively cultivated P. ruderale from Mexico, studied by Lara et al. [34], presented moisture values around $91.0 \%$, which are probably due to the applied irrigation. On the other hand, the species studied, P. oleracea, presented a lower water content than that found by [35], with a value of $92.9 \%$, and that found by [36], with a value of $91.23 \%$ in a wild environment. The diversity of environmental and geoclimatic conditions may be the cause of the difference in physicochemical properties, among which is moisture. The results obtained in this study are similar to those of [37], carried out in leaves of Greek P. oleracea from Mediterranean conditions, with $88.16 \%$ moisture.

However, the result obtained is within the normal moisture content for green leafy vegetables and shows a very stable foliar parameter for both species. High water content tends to decrease the energy density of food, making it important in obesity diets, and should be considered a true nutrient that ought to be part of the diet [38]. The higher water content in wild species may be due to the greater sponginess of the soil and the greater retention of water available to the plant in these wild conditions.

In this study, the highest total minerals content was found in P. oleracea, both wild and cultivated. The results obtained were higher than those observed in [35] in research with $1.22 \mathrm{~g} \cdot 100 \mathrm{~g}^{-1}$ on the same wild species from Brazil. The obtained ash results of our study are in concordance with [37], which found $2.40 \%$ ash in Greek P.oleracea. On the contrary, the ash in P. ruderale was higher compared to that obtained by [34], with $0.9 \mathrm{~g} \cdot 100 \mathrm{~g}^{-1}$ fresh weight in cultivated Mexican species, and lower than that obtained by [33], with $2.04 \mathrm{~g} \cdot 100 \mathrm{~g} \mathrm{~g}^{-1}$ in wild Mexican species. This may be due to the growing conditions and edaphoclimatic characteristics of the respective geographical areas, especially in the case of $P$. ruderale, which is a plant native to South America. As ash is an index of the total mineral content in food, its levels in plants suggest the considerable availability of these constituents, which are considered essential for humans.

In the analysis of the protein obtained in this study, the wild species of $P$. ruderale showed a value very close to that found by [34] in P. ruderale, with a result of $1.8 \mathrm{~g} \cdot 100 \mathrm{~g}^{-1} \mathrm{fw}$; a lower content of this nutrient was found in its cultivated counterpart. Low content was found in P. oleracea in this study compared to hat reported by [35], with $2.03 \mathrm{~g} \cdot 100 \mathrm{~g}^{-1} \mathrm{fw}$. Conclusively, both species studied demonstrated low protein content when compared to 
some conventional fresh species such as parsley $\left(3.0 \mathrm{~g} \cdot 100 \mathrm{~g}^{-1} \mathrm{fw}\right)$, basil $\left(14.4 \mathrm{~g} \cdot 100 \mathrm{~g}^{-1} \mathrm{fw}\right)$, or mint (3.8 g.100 g $\left.\mathrm{g}^{-1} \mathrm{fw}\right)$ according to [39]. As these are products of conventional agriculture, conditions of high nitrogen fertilizer content may be the cause of these differences.

The total lipid content in Mediterranean P. oleracea reported by [39] was a value of $6.90 \mathrm{~g} \cdot 100 \mathrm{~g}^{-1} \mathrm{db}$. The Greek P. oleracea had $0.23 \mathrm{~g} \cdot 100 \mathrm{~g}^{-1} \mathrm{fw}$ of total fat according to the study carried out by [36], and our results corroborate that this species is an abundant source of vegetable fat. The same study highlights that fat is rich in omega family fatty acids, which are beneficial for human health. If compared to the values reported by [35], which are $0.36 \mathrm{~g} \cdot 100 \mathrm{~g}^{-1} \mathrm{fw}$, our P. oleracea exceeded the fat content, especially in cultivated conditions. When comparing the results reported by [34] in fat content for P. ruderale $\left(0.3 \mathrm{~g} \cdot 100 \mathrm{~g}^{-1}\right)$ on the fresh basis, it can be mentioned that the results obtained in this study from the fresh parts of cultivated species were superior, and even more so in wild species.

While the wild species of $P$. ruderale excelled in crude fiber content, surpassing the values $\left(2.17 \mathrm{~g} \cdot 100 \mathrm{~g}^{-1} \mathrm{dm}\right)$ of Mediterranean P. oleracea reported by [40] and the content of Swiss chard ( $\left.1.0 \mathrm{~g} \cdot 100 \mathrm{~g}^{-1}\right)$ by even more according to [39], the cultivated counterpart of $P$. ruderale and P. oleracea showed a lower level of crude fiber. Although the dietary fiber values found in this study are not high compared with the levels in parsley $\left(7.26 \mathrm{~g} \cdot 100 \mathrm{~g}^{-1}\right)$, fiber intake is essential to improving the digestion of food and in the prevention of certain diseases such as diabetes, atherosclerosis, obesity, and constipation [41]. However, due to the crude fiber values found in this study, both species are an attractive source of this nutrient. It should be added that factors such as the degree of maturity and the botanical variety together with different culinary processes can modify the fiber intake, as well as the other nutrients. It would be useful to compare the nutritional parameters of the fresh plants studied with those cooked in various ways such as stewed or boiled.

The highest calculated energy value was recorded in cultivated $P$. Ruderale, placing it above all the samples studied, although when compared with the Greek P. oleracea, it was lower $\left(61.3 \mathrm{kcal} \cdot 100 \mathrm{~g}^{-1} \mathrm{fw}\right)$. This caloric level is due to the greater amount of carbohydrates and fiber in this plant; however, it corresponds to a moderate caloric level [38]. The study carried out by [42] highlights that the highest nutrient density/energy density ratios determine the nutritional quality index that can be useful in food selection, as it is scientifically proven that diets with lower energy density can help maintain a healthy weight and improve nutritional quality. Digestible carbohydrates are an additional source of energy in diets. However, a low-carbohydrate diet can reduce the risk of cardiovascular diseases [43], so P. ruderale and P. oleracea may be beneficial in this regard when their leaves and stems are consumed as fresh vegetables.

In relation to minerals, the levels of calcium, potassium, and magnesium stand out as macrominerals; and iron and zinc as microminerals, while sodium levels are minimal due to the ability of plants cell to keep sodium low in response to environmental conditions [44]. This predisposition makes vegetables a good choice for low-sodium diets. In P. ruderale, calcium is abundant, especially in its cultivated species, whereas in wild P. oleracea, the potassium content stands out. In both species, the amount of magnesium is also high. This may be due to geochemical conditions, such as soil composition and hydric state, among other factors. The most important route for the uptake of macro and microminerals in plants is through the roots; however, it has been observed that other tissues can also absorb minerals. The size of the metal ions plays a predominant role in this process. The ability to accumulate minerals is not a common characteristic of plants; rather, it is an evolutionary response. In addition, magnesium is present as a constituent of the chlorophyll molecules, from which it is released by gastric and intestinal secretions when the leaves are consumed. Its consumption is necessary to maintaining a healthy body since, together with zinc, it participates in many biological processes. Moreover, both minerals are essential in eye health. Complementarily, zinc is an essential trace element and must be provided on a regular basis as part of a healthy diet; it participates in the modulation of the immune system, is involved in various cell metabolism functions, and plays an important role in maintaining the concentration of tocopherols in plants [45]. 
Both species of $P$. oleracea are projected as good sources of zinc, similar to spinach, which contains $0.5 \mathrm{mg} \cdot 100 \mathrm{~g}^{-1}$. The iron found in the study is uniform in cultivated and wild species. Iron is an essential microelement in food. According to [39], two conventional vegetables, watercress and spinach, are important sources of this element and with values of 1.30 and $2.27 \mathrm{mg} \cdot 100 \mathrm{~g}^{-1} \mathrm{fw}$, respectively, and the plants studied can compete with these. Furthermore, the iron content in the plants in this research was similar to the value found in Argentinian P. oleracea $\left(1.99 \mathrm{mg} \cdot 100 \mathrm{~g}^{-1} \mathrm{fw}\right)$ [46] and was surpassed by that of Brazilian P. oleracea (10.5 mg $100 \mathrm{~g}^{-1} \mathrm{fw}$ ) [36], both in wild growing conditions. Although our P. oleracea appears to be a species with promising levels of $\mathrm{Fe}$ and $\mathrm{Zn}$, and $P$. ruderale with $\mathrm{Fe}$ and $\mathrm{Ca}$, the interaction of these minerals with the crude fiber and total polyphenols present, should be considered since these factors negatively influence mineral bioavailability and may require more detailed studies. On the contrary, the micromineral copper positively intervenes in iron absorption. A contribution of microminerals such as $\mathrm{Fe}, \mathrm{Cu}$, and $\mathrm{Zn}$ is necessary for the biosynthesis of antioxidant enzymes that participate in the body's oxide-reduction reactions [37,47]. In general, wild greens contribute more to the dietary intake of minerals than wild fruits [48].

The DPPH assay is a preliminary test to study the antioxidant effect of the plants. In the research carried out by [49] on P. oleracea leaves grown in Egypt, antioxidant activity was determined by the DPPH method with $147.78\left(\mu \mathrm{mol} \mathrm{TE} \cdot 100 \mathrm{~g}^{-1} \mathrm{dm}\right)$. This result contrasts with those obtained in this study for P. oleracea, which significantly exceeding the antioxidant content. In a recent study by [33], the antioxidant values were reported in P. oleracea $\left(2378.2 \mu \mathrm{mol} \mathrm{TE} \cdot 100 \mathrm{~g}^{-1} \mathrm{dm}\right)$ and P. ruderale $\left(6355.0 \mu \mathrm{mol} \mathrm{TE} \cdot 100 \mathrm{~g}^{-1} \mathrm{dm}\right)$, as raw materials obtained by the same method, with a difference in the preparation of samples and reagents. The antioxidant levels found in P. ruderale exceed those found in our study and do not reach those of $P$. oleracea, which may be due to the fact that the results are expressed as dry material. The antioxidant levels suggest $P$. oleracea as a very promising product. Similarly, the antioxidant content of $P$. ruderale leaves stands out, whose results, expressed on a fresh weight basis ( $\mathrm{fw}$ ), were not able to be contrasted due to the lack of publications. The review article by Marquez et al. [50] corroborates that most articles on P. ruderale have been published in the areas of biological and pharmacological science in the last 39 years.

It can be highlighted that the results of this study distinguish the species P. oleracea and $P$. ruderale, characteristic of the Mediterranean spring-summer season, as powerful sources of antioxidants, which, in general, reverse the damage caused by oxidative stress and prevent the appearance of pathologies that involve it. According to the database [47], vegetables with similar values in the content of total antioxidants are fresh arugula, with $5998 \mu \mathrm{mol} \mathrm{TE} \cdot 100 \mathrm{~g}^{-1} \mathrm{fw}$, and fresh spinach, with $5432 \mu \mathrm{mol} \mathrm{TE} \cdot 100 \mathrm{~g}^{-1} \mathrm{fw}$. Much higher is fresh parsley, with $28,865 \mu \mathrm{mol} \mathrm{TE} \cdot 100 \mathrm{~g}^{-1} \mathrm{fw}$. The results were determined by the ORAC test.

Total phenolic content had been reported to be associated with total antioxidant activity in both studied species. The higher recorded content was for wild samples. The research in [51] established the variation of total phenols of the Malaysian cultivars of $P$. oleracea in the range of $127 \pm 13$ to $478 \pm 45$ (mg GAE$\cdot 100 \mathrm{~g}^{-1} \mathrm{fw}$ ). The values found in our study for wild $P$. oleracea are close to the levels reported but, on the contrary, cultivated species presented lower values. The correlation analysis between components confirms that the richness of antioxidants is strongly related to the presence of total polyphenols in P. oleracea, although its wild species far exceeds that cultivated by organic techniques. Additionally, for $P$. ruderale there is no strong correlation between antioxidant and phenolic compounds, suggesting the presence of other antioxidant components such as anthocyanins, vitamins, or carotenoids, which requires further investigation.

Phenolic compounds are present in plants and take part in their defense, while for humans they have many benefits [52]. In the current study, the content of phenolic compounds showed significant variability between growing systems and species. A study conducted by [53] asserted that phenolic content fluctuated between different growing conditions. 
As indicated by the authors of [54], the amount of hydroxycinnamic acids depend on the vegetative progress of the plants, and its highest content is found in developing leaves that have greater metabolic activity. This means that in P. oleracea, in our study, gallic acid, rutin, and luteolin were not detected, and apigenin was only detected in organic cultivation conditions, probably collected in an optimal state of development, possibly due to genetic factors, but also due to a very mature state of the plant. In contrast, in other work, quercetin and kaempferol were not found in Turkish P. oleracea [55], so the plant's age may be important for the synthesis of these compounds. Ferulic and rosmarinic acid were not found in our samples of Malaysian P. oleracea, in contrast to [51]. Chlorogenic acid was the dominant hyrdoxycinnamic acid in P. ruderale. The polyphenolic profile study carried out is in line with the correlations made previously with the content of total phenolic content (TPP). In P. oleracea, antioxidants and phenols have a strong relationship despite the absence of some polyphenolic compounds in its profile, especially flavonoids. In contrast, P. ruderale, whose polyphenolic profile showed a greater amount of compounds, especially flavonoids, provided moderate antioxidant power. This indicates that this species has other bioactive compounds such as antioxidants that could be the subject of future research.

In the research conducted by Udeagha et al. [56], they assert that chlorophyll is involved in the synthesis of cell growth molecules, making it a key indicator of the physical state of the plant, reflecting its photosynthetic capacity, productivity, and stress level, among other aspects. Considering that, due to the amount of total chlorophyll, spinach is the raw material par excellence for the industrial extraction of chlorophyll, with an average of $16 \mu \mathrm{g} \cdot \mathrm{g}^{-1}$. It was observed that the study species showed a moderate level of chlorophyll in cultivated $P$. ruderale, and low levels in both P. oleracea growing systems. Wild P. ruderale showed a considerable level of total chlorophyll. On the other hand, chlorophyll values as technical-scientific information allows the identification of superior genotypes in the genetic improvement process to improve productivity. In addition, according to [57], chlorophyll is a bioactive component that reduces high levels of cholesterol and triglycerides and can improve health in a balanced diet with the intake of green leafy vegetables such as the undervalued species of this study. These species can also add color to gastronomic dishes due to their organoleptic qualities. Furthermore, natural chlorophylls have an effect on inflammation and wound healing, and prevent lipid peroxidation [58].

The nitrate content determined in this study was shown to be higher in wild species than in their cultivated counterparts. According to [59], regarding the classification of vegetables in the content of nitrates, $P$. ruderale belongs to the medium category, with a nitrate range of 500-1000 $\mathrm{mg} \mathrm{NO}_{3}{ }^{-} \cdot \mathrm{kg}^{-1} \mathrm{fw}$, and P. oleracea to the low category (200-500 $\left.\mathrm{mg} \mathrm{NO}_{3}{ }^{-} \cdot \mathrm{kg}^{-1} \mathrm{fw}\right)$. Nitrates are naturally occurring compounds in the environment due to the nitrogen cycle, but they can be altered by various agricultural practices. Nitrate quantification is used to diagnose the nutritional status of plants, particularly crop plants, as they accumulate nitrates in their chloroplasts. Nitrate itself is relatively toxic. Its toxicity is determined by its conversion to nitrite, which can be influenced by agronomic factors, and sometimes by processing or cooking techniques [60]. To comply with the hygienic-sanitary characteristics, the $\mathrm{WHO} / \mathrm{FAO}$ acceptable daily intake is $3.7 \mathrm{mg} \mathrm{NO}{ }^{-} \cdot \mathrm{kg}^{-1}$ of body weight, expressed as nitrate ions. However, some studies report that nitrate or diets moderately rich in this chemical component can induce a reduction in pressure [61,62]. Principally, nitrate concentration in vegetables varies according to climatic conditions and agronomic crop management, as well as post-harvest storage conditions [63,64]. Nitrates accumulate in plant vacuoles depending on the fraction absorbed from the soil. Subsequently, this compound is reduced to ammoniacal and amino forms for the formation of protein. The reduction process is conditioned by two enzymes that require metal cofactors such as iron and molybdenum. It is possible that organic cultivation conditions favor a balance of factors that cause a reduction, decreasing the concentration of nitrates in the edible leaves [65]. There is a clear need for future studies in antinutritional compounds to ensure the complete safety of these undervalued plants. 
The $\mathrm{pH}$ values of the aerial parts of wild species were higher than in their cultivated relatives. At the same time, the highest total acidity was found in the cultivated species. Both parameters indicate the presence of organic acids in the samples. The influence of $\mathrm{pH}$ on the assimilation of macro and micronutrients may be the most important factor, and at the same time, the $\mathrm{pH}$ and the total titratable acidity influence its organoleptic properties, giving a specific acid taste to the plants. Variations in these parameters can be attributed to environmental and cultivation conditions. In this sense, wild growing conditions can generate more palatable species from an organoleptic point of view by balancing their acids.

The statistical treatments applied indicated low variability in most of the nutritional values in P. ruderale (wild and organically cultivated). The small number of samples influenced the width of confidence intervals for bioactive compounds. The $p$-value corroborated significant differences in the parameters studied according to the growing conditions. The study of correlations between nutritional and bioactive compounds as quality parameters showed different degrees of correlation between them. In P. ruderale, highly significant negative relationships prevailed, while in P. oleracea, the significant relationships were mostly positive. The absence of strong relationships between $\mathrm{Zn}$ (P. oleracea), $\mathrm{K}$, and $\mathrm{Na}$ (P. ruderale) may be due to species-specific biosynthesis/transport processes that are influenced by geoclimatic conditions during growth depending on the harvest period, as suggested by $[58,66]$. The complete relationship between $\mathrm{Na}$ and $\mathrm{P}$ (P. oleracea) can be explained by the fact that the studied species are halophyte plants [67]. The correlations of different degrees found between compounds in both plants were weak, especially for total chlorophyll (P. oleracea). This might be due to common factors in the secondary metabolite's synthesis pathway, and in the case of chlorophyll, there is a dependence on foliar anatomy [68].

The analysis of the volatiles of fresh leaves showed specificity, and each species could be differentiated from others based on its aroma profile, which is strongly influenced by volatile components. The volatile analysis showed that monoterpenoids and unsaturated hydrocarbons were the most common volatile families in P. ruderale, and benzenoids were the most common in P. oleracea. Terpenoid compounds such as aldehydes and terpenes possibly contribute to antioxidant properties [69]. Under abiotic and biotic stress conditions, the production of benzenoid family metabolites is intensified; the same influence is exerted by heat stress, which intensifies the biosynthesis of benzenoids [70]. Fatty alcohols were found to be distinctive in P. oleracea. Most alcohols displayed an unmistakable fragrance of green scents and contributed to the perception of grassiness [71]. Medium-chain aldehydes were found to be homogeneous in the cultivated and wild species of both plants. The components of this family, especially (E)-2-hexenal, are known as green leaf aldehydes, which provide a characteristic scent. In addition, this constituent may be involved in the abiotic stress response [72]. Sesquiterpenoids predominated in wild P. ruderale and ketones predominated in cultivated $P$. oleracea. Sesquiterpenoids may play a significant role in human health due to their potential in preventing cardiovascular disease and cancer [73].

Among the minority families, organoheterocyclic and organooxygen compounds stood out in P. oleracea, as well as the family of alcohols, whose compounds are identified as major predictors for the freshness index [74]. The pyrazine family predominated in P. oleracea under both growing conditions. Pyrazines are considered a key family in intensity of smell in nature [75]. The volatiles analyzed showed a difference in the relative abundance of the majority and minority chemical groups found in this study. Aroma properties depend on the combination of volatiles and their concentrations, and can be an index of quality.

\section{Materials and Methods}

\subsection{Plants Materials}

P. oleracea (purslane) is an annual herb that has become naturalized throughout the world; it is considered a weed in some regions. The stems, leaves, and flowers are edible. It has a slightly acidic and salty taste and can be eaten fresh in salad or cooked as a leafy vegetable [76]. P. ruderale is an annual herb native to Central and South America, but is adapted to different edaphoclimatic conditions. It is known as "rupay wachi" and 
"quirquiña", among other common names [77]. This species is a wild herb with a strong and distinctive flavor; the leaves and tender stems are commonly used for salads and spicy sauces [78]. In addition, both plants have some phytopharmaceutical properties, provided by their biologically active compounds.

The species were collected between June-July 2020 from two environments along the Valencian coast (Spain): (1) organic farming and (2) wild conditions. Organic cultivation methods were carried out on the Unió de Llauradors i Ramaders farm, which was organic certified 18 years ago. The area is located within $39^{\circ} 45^{\prime} 13^{\prime \prime}$ North and $0^{\circ} 12^{\prime} 21^{\prime \prime}$ West, with SCI code ES0000148 [79]. The edible aerial parts such as leaves and small tender stems were separated and used for extractions and analytical quantification of bioactive compounds; methanolic extracts were prepared to determine total antioxidants, and acetone extracts to determine the chlorophyll content, as well as an aqueous extract for total polyphenols and other chemical constituents such as nitrates, $\mathrm{pH}$, and total acidity. The rest of the determinations were performed with plant matter dried to a constant weight in an autoclave (J.P. Selecta) at $70 \pm 0.1{ }^{\circ} \mathrm{C}$. The dry vegetable fraction was ground with a grinding mill (Retsch KG-5657 Haan, Remscheid, Germany) to obtain a fine powder $(250 \mu \mathrm{m})$ and stored in high-density polyethylene bottles under refrigeration conditions at $4{ }^{\circ} \mathrm{C}$ for subsequent analysis (nutritional and mineral compositions).

\subsection{Chemical Reagents}

Solutions of $80 \%(v / v)$ methanol and $80 \%(v / v)$ acetone were prepared from analytical grade reagents. The chemicals were sodium carbonate, citric acid, boric acid, sulfuric acid, hydrochloric acid, phosphoric acid, lanthanum (III) chloride, and sodium hydroxide (Scharlau). Trolox (6-hydroxy-2,5,7,8, -tetramethyl-chroman-2-carboxylic acid), 2,2'-azobis-2methyl-propanimidamide, 1,1-diphenyl-2-picrylhydrazyl (DPPH), Folin-Ciocalteu reagent (FCR), and gallic acid were purchased from Sigma-Aldrich Co (Taufkirchen, Germany). Water was prepared using a Water Still Aquatron A4000 distiller. Standard references for phenolic compounds were from Sigma-Aldrich Co., St. Louis, MI, USA.

\subsection{Nutritional Characteristics}

Prior to sample analysis, all analytical methods were optimized and fine-tuned for the specific analysis of this type of matrix. Three replicates were performed for each analysis.

\subsubsection{Proximate Composition}

Analysis was carried out by official methods [80]: moisture (AOAC 984.25), crude protein (AOAC 984.13), fat (AOAC 983.23), crude fiber (AOAC 991.43), and ash (AOAC 923.03). The carbohydrate content was calculated by difference. The results were expressed in $\mathrm{g} \cdot 100 \mathrm{~g}^{-1}$ fresh weight ( $\mathrm{fw}$ ).

\subsubsection{Mineral Composition}

The samples were subjected to digestion in accordance with method AOAC 985.35. The samples were calcined in a Carbolite CWF 1100 chamber furnace at $550{ }^{\circ} \mathrm{C}$, and the ashes were dissolved with concentrated $\mathrm{HCl}$ until a $2 \% \mathrm{HCl}$ solution was obtained. Calibration curves were established using working standards for each element. The analytical curves were obtained with a linear response for the selected concentration ranges. Mineral analysis was performed by atomic absorption spectroscopy (AAS) in a THERMO elemental AA series Spectrometer (spectrophotometer), v.11.03 software, and hollow cathode lamps for each element, except for phosphorus, which was analyzed by colorimetry [80].

\subsection{Non-Nutritional Compounds}

To determine total antioxidants, the $0.8 \mathrm{~g}$ of fresh leaves and small tender stems were mixing in $5 \mathrm{~mL}$ of methanol solution $(80 \% \mathrm{v} / \mathrm{v})$ and stirred for $1 \mathrm{~h}$ at room temperature by an SO1 orbital shaker (Bibby Stuart Scientific, Staffordshire, UK). Then, reagent was added to measure the effects of the extract on the DPPH radical. The calibration curve was 
obtained with the Trolox standard. The summary process and resulting reaction are shown in Figure 3a.

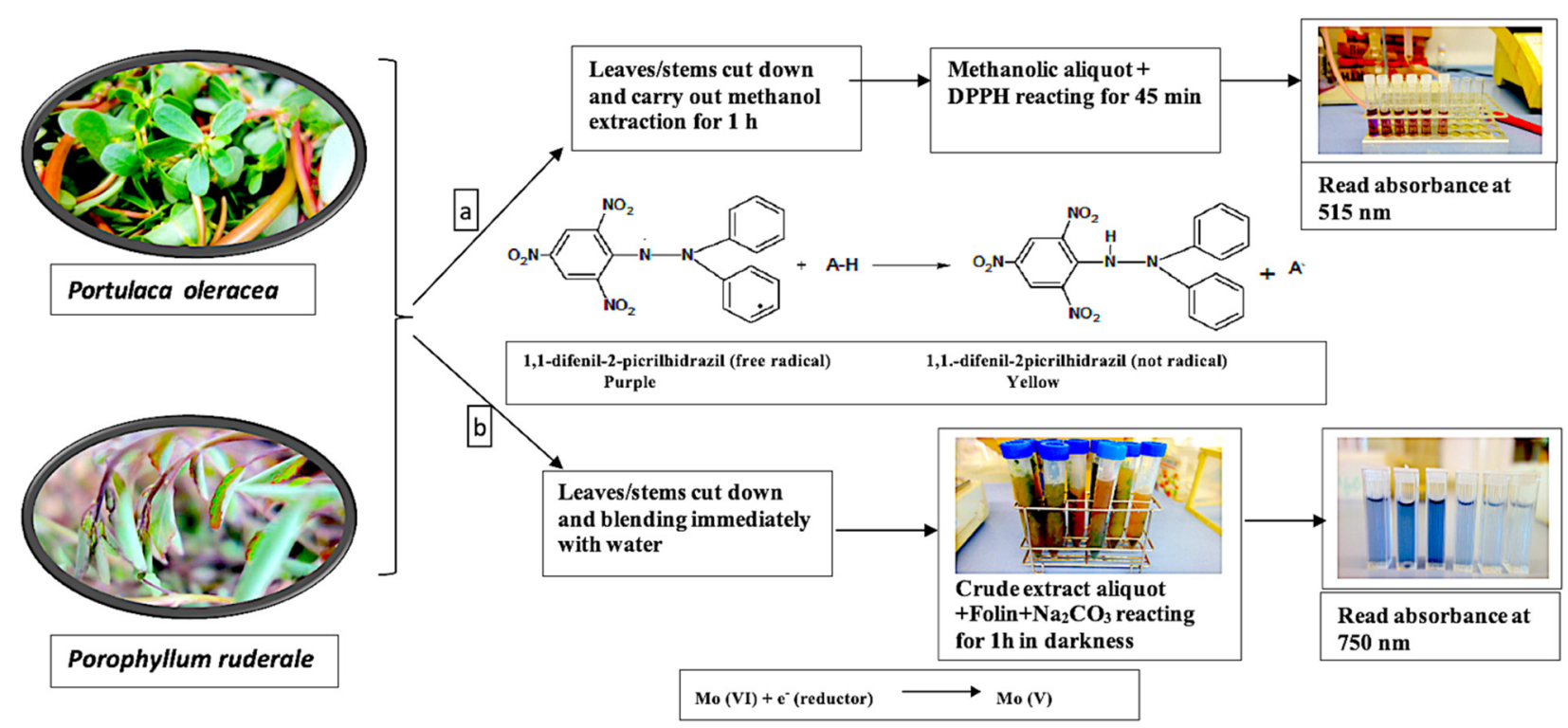

Figure 3. Reaction process in the quantification of bioactive constituents: (a) total antioxidants with the reaction of the DPPH radical; (b) total polyphenols with electron transfer reaction with the FCR.

To determine the total phenolic content, the aerial parts of fresh plants were crushed with water at a ratio of 2:1 (solvent: plant) and immediately reacted with FCR. The calibration curve was obtained with the gallic acid standard. The summary of the process and the reaction are show in Figure 3b.

Prior to the analysis of the samples, all analytical methods were optimized and tuned for the specific analysis of this type of matrix. Table 5 shows the values of linearity, calibration curve, linear range, and retention time (Tr) for the main non-nutritional compounds.

Table 5. Linearity, calibration curve, linear range, and retention time for main non-nutritional compounds.

\begin{tabular}{ccccc}
\hline Compound & Calibration Curve & Linearity & Linear Range & $\begin{array}{c}\text { Tr } \\
\text { (min) }\end{array}$ \\
\hline AOT & $\mathrm{y}=-0.1347 \mathrm{x}+1.0678$ & $\mathrm{R}^{2}=0.9783$ & $0.3-1.3 \mu \mathrm{M}$ & - \\
TPP & $\mathrm{y}=0.0018 \mathrm{x}+0.0182$ & $\mathrm{R}^{2}=0.9898$ & $0-400 \mathrm{ppm}$ & - \\
Gallic acid & $\mathrm{y}=25.36 \mathrm{x}+21.562$ & $\mathrm{R}^{2}=0.9992$ & $2-350 \mathrm{ppm}$ & 6.39 \\
Chlorogenic acid & $\mathrm{y}=25.567 \mathrm{x}+32.541$ & $\mathrm{R}^{2}=0.9998$ & $2-300 \mathrm{ppm}$ & 16.63 \\
Caffeic acid & $\mathrm{y}=45.356 \mathrm{x}+37.156$ & $\mathrm{R}^{2}=0.9990$ & $1.72-220 \mathrm{ppm}$ & 17.74 \\
$p$-Coumaric acid & $\mathrm{y}=60.223 \mathrm{x}+228.38$ & $\mathrm{R}^{2}=0.9992$ & $3-440 \mathrm{ppm}$ & 21.26 \\
Myricetin & $\mathrm{y}=41.599 \mathrm{x}+10.346$ & $\mathrm{R}^{2}=0.9987$ & $0.75-48 \mathrm{ppm}$ & 6.26 \\
Ruine & $\mathrm{y}=20.071 \mathrm{x}+5.5868$ & $\mathrm{R}^{2}=0.9984$ & $1.4-94 \mathrm{ppm}$ & 7.02 \\
Quercetin & $\mathrm{y}=44.696 \mathrm{x}+26.656$ & $\mathrm{R}^{2}=0.9984$ & $1.6-110 \mathrm{ppm}$ & 8.16 \\
Luteolin & $\mathrm{y}=21.996 \mathrm{x}-10.039$ & $\mathrm{R}^{2}=0.9997$ & $1.5-98 \mathrm{ppm}$ & 8.59 \\
Kaempherol & $\mathrm{y}=51.019 \mathrm{x}+23.177$ & $\mathrm{R}^{2}=0.9986$ & $1.5-97 \mathrm{ppm}$ & 9.13 \\
Apigenin & $\mathrm{y}=31.051 \mathrm{x}+18.277$ & $\mathrm{R}^{2}=0.9985$ & $1.5-95 \mathrm{ppm}$ & 9.38 \\
\hline
\end{tabular}

\subsubsection{Total Antioxidants}

The $25 \mathrm{ppm}$ DPPH solution was prepared in $80 \%$ methanol $(v / v)$ and $3.9 \mathrm{~mL}$ of this solution was mixed with $0.1 \mathrm{~mL}$ of methanolic extract aliquot to initiate the reaction. After incubation for $45 \mathrm{~min}$ at $23^{\circ} \mathrm{C}$, the progress of the reaction was monitored at $515 \mathrm{~nm}$ [81]. Trolox was used as the standard for analysis. The results were expressed as $\mu \mathrm{mol}$ Trolox equivalents per $100 \mathrm{~g}$ of fresh weight ( $\mu \mathrm{mol} \mathrm{TE} \cdot 100 \mathrm{~g}^{-1} \mathrm{fw}$ ). 


\subsubsection{Total Phenolic Content}

The optimized Folin-Ciocalteu method [82] consisted of preparing a series of spectrophotometric cuvettes with $50 \mu \mathrm{L}$ of aqueous extract aliquot. To this was added $0.5 \mathrm{~mL}$ of the FCR (previously diluted with 1:10 $v / v$ water). Before $8 \mathrm{~min}, 0.5 \mathrm{~mL}$ of $6 \%(w / v)$ $\mathrm{Na}_{2} \mathrm{CO}_{3}$ solution was added. After the reaction, the absorbance at $750 \mathrm{~nm}$ was measured by spectrophotometer (JENWAY $6715 / \mathrm{UV}-\mathrm{Vis}$ ). The results are expressed as mg gallic acid equivalents per $100 \mathrm{~g}$ of fresh weight $\left(\mathrm{mg}\right.$ GAE $\left.\cdot 100 \mathrm{~g}^{-1} \mathrm{fw}\right)$.

\subsubsection{Polyphenols Profile by HPLC}

The sample ( $2 \mathrm{~g}$ dry leaves) was subjected to direct solvent extraction $(15 \mathrm{~mL})$ of $75 \%$ ethanol $(v / v)$ with agitation on an orbital shaker for $2 \mathrm{~h}$, followed by centrifugation and filtration. The extracted phenolic acid and flavonoids were individually quantified and separated through an HPLC system (HPLC, Agilent 1220 Infinity LC) equipped with a UV detector. The analytical column was a Brisa C18 $(150 \times 4.6 \mathrm{~mm}$, particle size $=3 \mu \mathrm{m}$, Teknokroma). The mobile phase contained water with $0.1 \%$ formic acid (A) and methanol with $0.1 \%$ formic acid. The temperature was set at $30{ }^{\circ} \mathrm{C}$ and the sample injection volume was $10 \mu \mathrm{L}$. The chromatography was performed under the following conditions:

Hydroxycinnamic acids: flow rate $1.0 \mathrm{~mL} / \mathrm{min}$ flow rate; gradient program: 0-8 $\mathrm{min}$ $7 \%$ B, 8-13 min 30\% B, 13-48 $\min 66 \%$ B, 48-50 min 66\% B, 50-56 min 100\% B, 56-65 min $7 \%$ B. Polyphenols were detected by monitoring the absorbance at $280 / 320 \mathrm{~nm}$ [83].

Flavonoids: flow rate $0.8 \mathrm{~mL} / \mathrm{min}$ flow rate; gradient program: $0-10 \mathrm{~min} 40 \% \mathrm{~B}$, 10-15 $\min 100 \%$ B, 15-20 $\min 40 \%$ B, 20-25 $\operatorname{min~} 40 \%$ B at absorbance $360 \mathrm{~nm}$ [84]. The results were expressed as $\mu \mathrm{g} \cdot \mathrm{g}^{-1}$ fresh weight.

\subsubsection{Chlorophylls: a, b, Total}

The extraction of chlorophylls was carried out by adapting the method proposed in [85]. The ground aerial parts were suspended in pigment extraction solvent $(80 \%$ acetone $v / v$ ), filtered through filter paper to avoid turbidity, and brought up to a volume of $50 \mathrm{~mL}$ with the same extraction solvent. Solutions were measured spectrophotometrically at $645 \mathrm{~nm}, 653 \mathrm{~nm}$, and $663 \mathrm{~nm}$. The results were expressed as $\mu \mathrm{g} \cdot \mathrm{g}^{-1} \mathrm{fw}$ on a per sample basis.

\subsection{Other Chemicals: Nitrates, Ph and Total Acidity}

Aqueous extracts from fresh aerial parts were prepared in a 1:2 $(w / v)$ ratio at a temperature lower than $30^{\circ} \mathrm{C}$ by mechanical grinding. Nitrates $\left(\mathrm{mg} \mathrm{NO}_{3}^{-} \cdot \mathrm{kg}^{-1} \mathrm{fw}\right)$ and $\mathrm{pH}$ were measured directly by $\mathrm{pH}$ and ION-Meter GLP 22+ (CRISON) equipment and with the respective electrodes, after calibrating each electrode. The total acidity was determined potentiometrically with $0.05 \mathrm{~N} \mathrm{NaOH}$ solution, and the results are expressed as a percentage of citric acid.

\subsection{Volatiles Profile Analysis}

Dynamic headspace sampling was used to analyze the volatiles present in fresh leaf and stem samples. Extraction of volatile compounds was carried out using the HS-SPME technique according to [86]. The analysis was performed by a $6890 \mathrm{~N}$ gas chromatography and mass spectrometry (GC-MS) networked to a 5973 inert mass selective detector (Agilent Technologies). The analytical conditions were as follows: stationary phase HP-5MS J\&W silica capillary column $(30 \mathrm{~m} \times 0.251 \mathrm{~mm}$ i.d. $\times 0.25 \mu \mathrm{m}$ thickness film; $5 \%$ phenyl- $95 \%$ methylpolysiloxane); helium carrier gas at a constant flow of $1 \mathrm{~mL} \mathrm{~min}^{-1}$; transfer line maintained at $220^{\circ} \mathrm{C}$. Initial temperature $\left(40{ }^{\circ} \mathrm{C}\right)$ for $1 \mathrm{~min}$, Ramp 1 from $5^{\circ} \mathrm{C} \mathrm{min}-1$ up to $200{ }^{\circ} \mathrm{C}$ for $1 \mathrm{~min}$, and Ramp 2 from $15^{\circ} \mathrm{C} \mathrm{min}{ }^{-1}$ up to $250{ }^{\circ} \mathrm{C}$ for $3 \mathrm{~min}$. The electron impact mode with ionization energy of $70 \mathrm{eV}$ (source temperature $225^{\circ} \mathrm{C}$ ) was used for detection by the mass spectrometer, and the acquisition was performed in scan mode (mass range $m / z$ 35-350 amu). 


\subsection{Statistical Analysis}

Datasets from wild and cultivated species were processed using Statgraphics Plus version 5.1 (Manugistics Inc., Rockville, MD, USA) for means, standard errors, and correlations. The analysis of variance (multivariate ANOVA; at a significant level of $p<0.05$ ) was performed according to a completely randomized design with three replicates. Differences between groups were identified with multiple comparisons of means (Tukey contrast), and the bivariate statistical method was applied to determine the relationship between the various qualitative characteristics of the plants studied. The independent variables defined the qualitative parameters, and the dependent variables were the species and the growing conditions. Pearson linear correlation coefficients (r) between traits were calculated from regression analyses between pairs of traits. The confidence limits used in this study were based on $95 \%(p<0.05)$, and in polyphenol individuals, on $99 \%(p<0.01)$.

\section{Conclusions}

The results of this study provide a basis for the characterization of nutritional, organoleptic, and non-nutritional compounds of $P$. ruderale and P. oleracea. These undervalued plants have significant crude fiber, carbohydrate, mineral, and chlorophyll content, and are a good source of antioxidants and phenolic compounds. Studies of polyphenolic and volatile profiles show that both species possess bioactive compounds with functional properties. These preliminary data reveal that these plants are a promising source of new natural antioxidants, as well as possible material for new improved varieties. Their production potential can boost local economies and ensure ecological security, as the species studied grow in diverse habitat conditions. In addition, their nutritional quality and promising amount of bioactive components will greatly contribute to knowledge about these undervalued plants that, due to their nutrient-dense characteristics and low energy content, could be part of health diets.

Author Contributions: T.F.F. and M.D.R. planned the study. M.D.R. supervised the research and resources. T.F.F. and M.D.G.-M. performed validation and formal analysis. T.F.F. and M.D.R. performed data curation. T.F.F. performed the statistical analyses. T.F.F. and M.D.R. drafted the manuscript. All authors have read and agreed to the published version of the manuscript.

Funding: This research did not receive external funding.

Institutional Review Board Statement: Not applicable.

Informed Consent Statement: Not applicable.

Data Availability Statement: The individual data presented in this study are available on request from the corresponding author.

Acknowledgments: The authors thank Manuel Figueroa from the local Ecological Cooperative, who kindly provided the materials used in this study expeditiously and in sufficient quantity, for his direct collaboration.

Conflicts of Interest: The authors declare that they have no known competing financial interests or personal relationships that could have appeared to influence the work reported in this paper.

\section{References}

1. Waldron, A.; Miller, D.; Redding, D.; Mooers, A.; Kuhn, T.; Nibbelink, N.; Roberts, T.; Tobias, J.; Gittleman, J. Reductions in global biodiversity loss predicted from conservation spending. Nature 2017, 551, 364-367. [CrossRef]

2. Spina, M.; Cuccioloni, M.; Sparapani, L.; Acciarri, S.; Eleuteri, A.M.; Fioretti, E.; Angeletti, M. Comparative evaluation of flavonoid content in assessing quality of wild and cultivated vegetables for human consumption. J. Sci. Food Agric. 2008, 88, 294-304. [CrossRef]

3. Chatzopoulou, E.; Carocho, M.; Di Gioia, F.; Petropoulos, S.A. The beneficial health effects of vegetables and wild edible greens: The case of the mediterranean diet and its sustainability. Appl. Sci. 2020, 10, 9144. [CrossRef]

4. Khoury, C.; Bjorkman, A.; Dempewolf, H.; Ramirez-Villegas, J.; Guarino, L.; Jarvis, A.; Rieseberg, L.; Struik, P. Increasing homogeneity in global food supplies and the implications for food security. Proc. Natl. Acad. Sci. USA 2014, 111, 4001-4006. [CrossRef] [PubMed] 
5. Caetano, C.M.; Peña, C.R.D.; Maigual, J.J.L.; Vasquez, D.L.N.; Nunes, D.C.; Pazdiora, B.R. Mejoramiento participativo: Herramienta para la conservación de cultivos subutilizados y olvidados. Acta Agron. 2015, 64, 307-327. [CrossRef]

6. Willett, W.; Rockström, J.; Loken, B.; Springmann, M.; Lang, T.; Vermeulen, S.; Garnett, T.; Tilman, D.; DeClerck, F.; Wood, A.; et al. Food in the Anthropocene: The EAT-Lancet Commission on healthy diets from sustainable food systems. Lancet 2019, 393, 447-492. [CrossRef]

7. Clapp, J.; Moseley, W.G. This food crisis is different: COVID-19 and the fragility of the neoliberal food security order. J. Peasant Stud. 2020, 47, 1393-1417. [CrossRef]

8. Rizou, M.; Galanakis, I.; Aldawoud, T.; Galanakis, C. Safety of foods, food supply chain and environment within the COVID-19 pandemic. Trends Food Sci. Technol. 2020, 102, 293-299. [CrossRef] [PubMed]

9. Pardo-de-Santayana, M.; Tardio, J.; Blanco, E.; Carvalho, A.M.; Lastra, J.J.; San Miguel, E.; Morales, R. Traditional knowledge of wild edible plants used in the northwest of the Iberian Peninsula (Spain and Portugal): A comparative study. J. Ethnobiol. Ethnomed. 2007, 3, 27. [CrossRef]

10. Carvalho, A.M.; Barata, A.M. The Consumption of Wild Edible Plants. In Wild Plants, Mushrooms and Nuts: Functional Food Properties and Applications; Ferreira, I.C.F.R., Morales, P., Barros, L., Eds.; John Wiley \& Sons: Chichester, UK; Hoboken, NJ, USA, 2017; pp. 159-198.

11. Beilin, K.O. Messages from the Underground: Interspecies Memory in Times of the Climate Change. $452^{\circ} \mathrm{F}$. Rev. Teoría Lit. Lit. Comp. 2019, 21, 35-54.

12. de Aquino, D.R.M.; Flores, M.D.S.A. Plantas alimentícias não convencionais em Belém, Pará: Conhecimento, usos e segurança alimentar. Novos Cad. NAEA 2021, 24, 73-97. [CrossRef]

13. Disciglio, G.; Tarantino, A.; Frabboni, L.; Gagliardi, A.; Giuliani, M.M.; Tarantino, E.; Gatta, G. Qualitative characterization of cultivated and wild edible plants: Mineral elements, phenols content and antioxidant capacity. Ital. J. Agron. 2017, 12, 383-394. [CrossRef]

14. Bello, O.M.; Jagaba, S.M.; Bello, O.E.; Ogbesejana, A.B.; Dada, O.; Adetunji, C.C.; Abubakar, S.M. Phytochemistry, pharmacology and perceived health uses of non-cultivated vegetable Cyphostemma adenocaule (Steud. ex A. Rich.) Desc. ex Wild and R.B. Drumm: A review. Sci. Afr. 2019, 2, e00053. [CrossRef]

15. Crescente, G.; Piccolella, S.; Esposito, A.; Scognamiglio, M.; Fiorentino, A.; Pacifico, S. Chemical composition and nutraceutical properties of hempseed: An ancient food with actual functional value. Phytochem. Rev. 2018, 17, 733-749. [CrossRef]

16. Blanco-Salas, J.; Gutierrez-Garcia, L.; Labrador-Moreno, J.; Ruiz-Tellez, T. Wild Plants Potentially Used in Human Food in the Protected Area "Sierra Grande de Hornachos" of Extremadura (Spain). Sustainability 2019, 11, 456. [CrossRef]

17. Minde, J.; Venkataramana, P.; Matemu, A. Dolichos Lablab-an underutilized crop with futurepotentials for food and nutrition security: A review. Crit. Rev. Food Sci. Nutr. 2021, 61, 1-13. [CrossRef] [PubMed]

18. Omotayo, A.O.; Ijatuyi, E.J.; Ogunniyi, A.I.; Aremu, A.O. Exploring the Resource Value of Transvaal Red MilkWood (Mimusops zeyheri) for Food Security and Sustainability: An Appraisal of Existing Evidence. Plants 2020, 9, 1486. [CrossRef] [PubMed]

19. Pasta, S.; La Rosa, A.; Garfi, G.; Marceno, C.; Gristina, A.S.; Carimi, F.; Guarino, R. An updated checklist of the Sicilian native edible plants: Preserving the traditional ecological knowledge of century-old agro-pastoral landscapes. Front. Plant Sci. 2020, 11, 308. [CrossRef]

20. Torija-Isasa, M.; Matallana-González, M. A Historical Perspective of Wild Plant Foods in the Mediterranean Area. In Mediterranean Wild Edible Plants; Sánchez-Mata, M., Tardío, J., Eds.; Springer: New York, NY, USA, 2016. [CrossRef]

21. Kregiel, D.; Pawlikowska, E.; Antolak, H. Urtica spp.: Ordinary Plants with Extraordinary Propertie. Molecules 2018, $23,1664$. [CrossRef] [PubMed]

22. García-Herrera, P.; Morales, P.; Cámara, M.; Fernández-Ruiz, V.; Tardío, J.; Sánchez-Mata, M.C. Nutritional and phytochemical composition of Mediterranean wild vegetables after culinary treatment. Foods 2020, 9, 1761. [CrossRef]

23. Arranz, S.; Saura-Calixto, F.; Shaha, S.; Kroon, P. High contents of nonextractable polyphenols in fruit suggest that polyphenol contents of plant foods have been underestimated. J. Agric. Chem. 2009, 57, 7298-7303. [CrossRef] [PubMed]

24. Rodríguez, L.G.G.; Perea, J.M.; Anta, R.M.O. Los alimentos funcionales en el contexto de la dieta mediterránea. Mediterráneo Económico 2015, 27, 139-160.

25. Morales, R.; Tardío, J.; Aceituno, L.; Molina, M.; Pardo de Santayana, M. Biodiversidad y Etnobotánica en España. In Memorias Real Sociedad, Española de Historia Natural; Viejo Montesinos, J.L., Ed.; Real Sociedad Española de Historia Natural: Madrid, Spain, 2011; pp. 157-208.

26. Poonia, A.; Upadhayay, A. Chenopodium album Linn: Review of nutritive value and biological properties. J. Food Sci. Technol. 2015, 52, 3977-3985. [CrossRef] [PubMed]

27. Avato, P.; Argentieri, M.P. Brassicaceae: A rich source of health improving phytochemicals. Phytochem. Rev. 2015, 14, 1019-1033. [CrossRef]

28. Tardío, J.; de Cortes Sánchez-Mata, M.; Morales, R.; Molina, M.; García-Herrera, P.; Boussalah, N. Ethnobotanical and food composition monographs of selected Mediterranean wild edible plant. In Mediterranean Wild Edible Plants; Sánchez-Mata, M., Tardío, J., Eds.; Springer Science: New York, NY, USA, 2016; pp. 273-470. [CrossRef]

29. Jakubczyk, K.; Janda, K.; Watychowicz, K.; Lukasiak, J.; Wolska, J. Garden nasturtium (Tropaeolum majus L.) a source of mineral elements and bioactive compounds. Rocz. Panstw. Zakl. Hig. 2018, 69, 119-126. 
30. Panfili, G.; Niro, S.; Bufano, A.; D'Agostino, A.; Fratianni, A.; Paura, B.; Falasca, L.; Cinquanta, L. Bioactive compounds in wild Asteraceae edible plants consumed in the Mediterranean Diet. Plant Foods Hum. Nutr. 2020, 75, 540-546. [CrossRef]

31. Fukalova Fukalova, T.; García Martínez, M.D.; Raigón, M.D. Five undervalued edible species inherent to autumn-winter season: Nutritional composition, bioactive constituents and volatiles profile. Peer J. 2021, 9, e12488. [CrossRef]

32. Rocchetti, G.; Braceschi, G.P.; Odello, L.; Bertuzzi, T.; Trevisan, M.; Lucini, L. Identification of markers of sensory quality in ground coffee: An untargeted metabolomics approach. Metabolomics 2020, 16, 1-12. [CrossRef]

33. Arias-Rico, J.; Macías-León, F.J.; Alanís-García, E.; Cruz-Cansino, N.D.S.; Jaramillo-Morales, O.A.; Barrera-Gálvez, R.; RamírezMoreno, E. Study of edible plants: Effects of boiling on nutritional, antioxidant, and physicochemical properties. Foods 2020, 9 , 599. [CrossRef]

34. Lara, C.D.; Boettler, B.; Ovando, M. Diagnóstico del pápaloquelite en México Porophyllum ruderale (Jacq.) Cass. var. macrocephalum (DC.) Cronq. In Red Quelites; Márquez Ortíz, L., Ed.; Universidad Autónoma Chapingo: Chapingo, México, 2011; pp. $1-61$.

35. USDA: U.S. Department of Agriculture. National Nutrient Database for Standard Reference. Available online: https://fdc.nal. usda.gov/fdc-app.html\#/food-details/169274/nutrients (accessed on 5 July 2021).

36. Mangoba, P.M.A. Prospecção de Características Fitoquímicas, Antibacterianas e Físico-Químicas de Portulaca Oleracea L. (Beldroega). Dissertation Thesis, Porto Alegre, Brazil, 2015. Available online: https://lume.ufrgs.br/handle/10183/115207 (accessed on 9 October 2021).

37. Petropoulos, S.A.; Fernandes, Â.; Dias, M.I.; Vasilakoglou, I.B.; Petrotos, K.; Barros, L.; Ferreira, I.C. Nutritional value, chemical composition and cytotoxic properties of common purslane (Portulaca oleracea L.) in relation to harvesting stage and plant part. Antioxidants 2019, 8, 293. [CrossRef]

38. Carbajal Azcona, Á. Manual de Nutrición y Dietética; Departamento de Nutrición, Facultad de Farmacia: Madrid, Spain, 2013; pp. $1-367$.

39. BEDCA: Base de Datos Española de Composición de Alimentos. Available online: https://www.bedca.net/bdpub/index.php (accessed on 4 November 2021).

40. Kamal-Uddin, K.; Quan, L.; Haasan, M.; Motmainna, M.; Selamat, M. Purslane: A perspective plant source of nutrition and antioxidant. Plant Arch. 2020, 20, 1624-1630.

41. Aberoumand, A. Protein, fat, calories, minerals, phytic acid and phenolic in some plant foods based diet. J. Food Process Technol. 2011, 2, 1-4. [CrossRef]

42. Darmon, N.; Darmon, M.; Maillot, M.; Drewnowski, A. A nutrient density standard for vegetables and fruits: Nutrients per calorie and nutrients per unit cost. J. Am. Diet. Assoc. 2005, 105, 1881-1887. [CrossRef] [PubMed]

43. Idris, O.A.; Wintola, O.A.; Afolayan, A.J. Comparison of the proximate composition, vitamins (ascorbic acid, $\alpha$-tocopherol and retinol), anti-nutrients (phytate and oxalate) and the GC-MS analysis of the essential oil of the root and leaf of Rumex crispus L. Plants 2019, 8, 51. [CrossRef] [PubMed]

44. Blumwald, E. Sodium transport and salt tolerance in plants. Curr. Opin. Cell Biol. 2000, 12, 431-434. [CrossRef]

45. Hartikainen, H. Biogeochemistry of selenium and its impact on food chain quality and human health. J. Trace Elem. Med. Biol. 2005, 18, 309-318. [CrossRef]

46. Moscuzza, N. Verdolaga una alternativa saludable. Master's Thesis, Universidad FASTA, Mar de Plata, Argentina, 2016. Available online: http:/ / redi.ufasta.edu.ar:8080/xmlui/handle/123456789/1271 (accessed on 9 October 2021).

47. Available online: http://www.portalantioxidantes.com/antioxidantes (accessed on 17 October 2021).

48. Lenzi, A.; Orlandini, A.; Bulgari, R.; Ferrante, A.; Bruschi, P. Antioxidant and mineral composition of three wild leafy species: A comparison between microgreens and baby greens. Foods 2019, 8, 487. [CrossRef]

49. Youssef, K.M.; Mokhtar, S.M. Effect of drying methods on the antioxidant capacity, color and phytochemicals of Portulaca oleracea L. leaves. J. Nutr. Food Sci. 2014, 4, 1-6. [CrossRef]

50. Marques, E.A.; Oliveira, J.A.; Coelho, A.D.; Salimena, J.P.; Gavilanes, M.L. Porophyllum ruderale (Jacq.) Cass. A review of the last 39 years. Res. Soc. Dev. 2020, 9, e944975215. [CrossRef]

51. Lim, Y.Y.; Quah, E.P.L. Antioxidant properties of different cultivars of Portulaca oleracea. Food Chem. 2007, 103, 734-740. [CrossRef]

52. Oliveira, L.D.L.D.; Carvalho, M.V.D.; Melo, L. Health promoting and sensory properties of phenolic compounds in food. Rev. Ceres 2014, 61, 764-779. [CrossRef]

53. Sdouga, D.; Branca, F.; Kabtni, S.; Di Bella, M.C.; Trifi-Farah, N.; Marghali, S. Morphological Traits and Phenolic Compounds in Tunisian Wild Populations and Cultivated Varieties of Portulaca oleracea L. Agronomy 2020, 10, 948. [CrossRef]

54. Reyes, L.F.; Villarreal, J.E.; Cisneros-Zevallos, L. The increase in antioxidant capacity after wounding depends on the type of fruit or vegetable tissue. Food Chem. 2007, 101, 1254-1262. [CrossRef]

55. Erkan, N. Antioxidant activity and phenolic compounds of fractions from Portulaca oleracea L. Food Chem. 2012, 133, 775-781. [CrossRef]

56. Udeagha, A.U.; Shomkegh, S.A.; Daniel, K.S. An assesesment of leaf chlorophyll concentration of afforestation tree species in South-Eastern, Nigeria. J. For. Environ. Sci. 2016, 32, 205-211. [CrossRef]

57. Sharma, S.; Katoch, V.; Kumar, S.; Chatterjee, S. Functional relationship of vegetable colors and bioactive compounds: Implications in human health. J. Nutr. Biochem. 2021, 92, 108615. [CrossRef] 
58. Mzoughi, Z.; Chahdoura, H.; Chakroun, Y.; Cámara, M.; Fernández-Ruiz, V.; Morales, P.; Mosbah, H.; Flamini, G.; Snoussi, M.; Majdoub, H. Wild edible Swiss chard leaves (Beta vulgaris L. var. cicla): Nutritional, phytochemical composition and biological activities. Food Res. Int. 2019, 119, 612-621. [CrossRef]

59. Moreno, C.B.; Soto, K.; González, R.D. El consumo de nitrato y su potencial efecto sobre la salud cardiovascular. Rev. Chil. Nutr. 2015, 42, 199-205. [CrossRef]

60. AESAN: Agencia Española de Seguridad Alimentaria y Nutricion. Available online: http://www.aesan.gob.es/AECOSAN/ web/seguridad_alimentaria/subdetalle/nitratos.htm (accessed on 21 June 2021).

61. Sobko, T.; Marcus, C.; Govoni, M.; Kamiya, S. Dietary nitrate in Japanese traditional foods lowers diastolic blood pressure in healthy volunteers. Nitric Oxide 2010, 22, 136-140. [CrossRef]

62. Kapil, V.; Weitzberg, E.; Lundberg, J.O.; Ahluwalia, A. Clinical evidence demonstrating the utility of inorganic nitrate in cardiovascular health. Nitric Oxide 2014, 38, 45-57. [CrossRef]

63. Silva, L.F.L.E.; Souza, D.C.; Resende, L.V.; Nassur, R.D.C.M.; Samartini, C.Q.; Gonçalves, W.M. Nutritional evaluation of non-conventional vegetables in Brazil. An. Acad. Bras. Ciênc. 2018, 90, 1775-1787. [CrossRef] [PubMed]

64. Pardo-Marín, O.; Yusà-Pelechà, V.; Villalba-Martín, P.; Perez-Dasí, J.A. Monitoring programme on nitrates in vegetables and vegetable-based baby foods marketed in the Region of Valencia, Spain: Levels and estimated daily intake. Food Addit. Contam. 2010, 27, 478-486. [CrossRef] [PubMed]

65. Raigón, M.D.; García-Martínez, M.D.; Guerrero, C.; Esteve, P. Actividad de la nitrato reductasa y su relación con los factores productivos en lechuga. In Proceedings of the VII Congreso SEAE Zaragoza, Zaragoza, Spain, 18-23 September 2006.

66. Devkar, S.T.; Suryapujary, S.M.; Jagtap, S.D.; Katyare, S.S.; Hegde, M.V. Effect of macronutrient deficiency on withanolides content in the roots of Withania somnifera and its correlationship with molybdenum content. Pharm. Biol. 2015, 53, 518-523. [CrossRef] [PubMed]

67. Silva, V.N.B.; Vieira, L.R.; Sousa, C.A.F.; Souza, M.T., Jr. Morphological Changes in Portulaca oleracea L. under salt stress. In Proceedings of the Inovagri International Meeting, 4, Congresso Nacional de Irrigação e Drenagem, Fortaleza, Brazil; Simpósio Brasileiro de Salinidade, 3. 2017. Available online: https://www.alice.cnptia.embrapa.br/bitstream/doc/1088965/1/TC4800865 .pdf (accessed on 9 October 2021).

68. Peñaranda, J.C.; CRodrigo, G.; Ticona-Bustillos, A.R.; Valenzuela, E.; Ramos, S.; San Martin, A.; Ghezzi, F.; Almanza, G.R. Variación en la concentración de flavonoides y clorofila, y cambios en la morfología y anatomía foliar, debidos a radiación visible (PAR) o ultravioleta (UVA, UVB) en Baccharis Latifolia. Rev. Bol. Quim. 2020, 37, 210-222. [CrossRef]

69. Fan, Y.; Feng, H.; Liu, L.; Zhang, Y.; Xin, X.; Gao, D. Chemical components and antibacterial activity of the essential oil of six pyrrosia species. Chem. Biodivers. 2020, 17, e2000526. [CrossRef]

70. Misztal, P.K.; Hewitt, C.N.; Wildt, J.; Blande, J.D.; Eller, A.S.; Fares, S.; Goldstein, A.H. Atmospheric benzenoid emissions from plants rival those from fossil fuels. Sci. Rep. 2015, 5, 1-10. [CrossRef]

71. Baccouri, B.; Temime, S.B.; Campeol, E.; Cioni, P.L.; Daoud, D.; Zarrouk, M. Application of solid-phase microextraction to the analysis of volatile compounds in virgin olive oils from five new cultivars. Food Chem. 2007, 102, 850-856. [CrossRef]

72. Kunishima, M.; Yamauchi, Y.; Mizutani, M.; Kuse, M.; Takikawa, H.; Sugimoto, Y. Identification of (Z)-3:(E)-2-hexenal isomerases essential to the production of the leaf aldehyde in plants. J. Biol. Chem. 2016, 291, 14023-14033. [CrossRef]

73. Chadwick, M.; Trewin, H.; Gawthrop, F.; Wagstaff, C. Sesquiterpenoids lactones: Benefits to plants and people. J. Mol. Sci. 2013, 14, 12780-12805. [CrossRef]

74. Zakari, I.S.; N'guessan, A.; Dehaut, A.; Duflos, G. Volatile Compounds Selection via Quantile Correlation and Composite Quantile Correlation: A Whiting Case Study. Open J. Stat. 2016, 6, 995. [CrossRef]

75. Leidinger, W. ¿Por qué pica el ají? Notas químicas sobre el ají. Rev. Quim. PUCP 2020, 34, 22-25.

76. Megaloudi, F. Wild and cultivated vegetables, herbs and spices in Greek Antiquity (900 B.C. to 400 B.C.). Environ. Archaeol. 2005, 10, 73-82. [CrossRef]

77. Rzedowski, G.C.; Rzedowski, J. Manual de malezas de la región de Salvatierra, Guanajuato. In Flora del Bajío y de Regiones Adyacente; Centro Regional de Bajío, Ed.; Instituto de Ecología, A.C.: Veracruz, Mexico, 2004; pp. 1-315.

78. Loayza, I.; De Groot, W.; Lorenzo, D.; Dellacassa, E.; Mondello, L.; Dugo, G. Composition of the essential oil of Porophyllum ruderle (Jacq.) Cass. from Bolivia. Flavour Fragr. J. 1999, 14, 393-398. [CrossRef]

79. Soria García, J.M.; Romo, S.; Palacios Pastor, A.; García Picazo, A.; Aledón Catalá, T.; Calvo García, S. Evaluación de la conservación de los humedales costeros de la Comunidad Valenciana mediante imágenes de Landsat. In Teledetección: Humedales y Espacios Protegidos. XVI; Bustamante, J., Díaz-Delgado, R., Aragonés, D., Afán, I., García, D., Eds.; Asociación Española de Teledetección: Sevilla, Spain, 2015; pp. 354-357.

80. AOAC. Official Methods of Analysis of Official Analytical Chemists, 18th ed.; Association of Official Analitical Chemist (AOAC International): Washington, DC, USA, 2005.

81. Brand-Williams, W.; Cuvelier, M.E.; Berset, C. Use of free radical method to evaluate antioxidant activity. LWT-Food Sci. Technol. 1995, 28, 25-30. [CrossRef]

82. Singleton, V.L.; Rossi, J.A. Colorimetry of total phenolics with phosphomolybdic-phosphotungstic acid reagents. Am. J. Enol. Viticult. 1965, 16, 144-158. 
83. Plazas, M.; Prohens, J.; Cuñat, A.N.; Vilanova, S.; Gramazio, P.; Herraiz, F.J.; Andújar, I. Reducing capacity, chlorogenic acid content and biological activity in a collection of scarlet (Solanum aethiopicum) and Gboma (S. macrocarpon) eggplants. Int. J. Mol. Sci. 2014, 15, 17221-17241. [CrossRef]

84. Bae, H.; Jayaprakasha, G.K.; Jifon, J.; Patil, B.S. Extraction efficiency and validation of an HPLC method for flavonoid analysis in peppers. Food Chem. 2012, 130, 751-758. [CrossRef]

85. Hansmann, E. Pigment Analisys. In Handbook of Phycological Methods-Culture Methods and Grow the Measurements; Stein, J.R., Ed.; Cambridge University Press: Cambridge, UK, 1973; pp. 359-368.

86. Moreno, E.; Fita, A.; González-Mas, M.C.; Rodríguez-Burruezo, A. HS-SPME study of the volatile fraction of Capsicum accessions and hybrids in different parts of the fruit. Sci. Hortic. 2012, 135, 87-97. [CrossRef] 